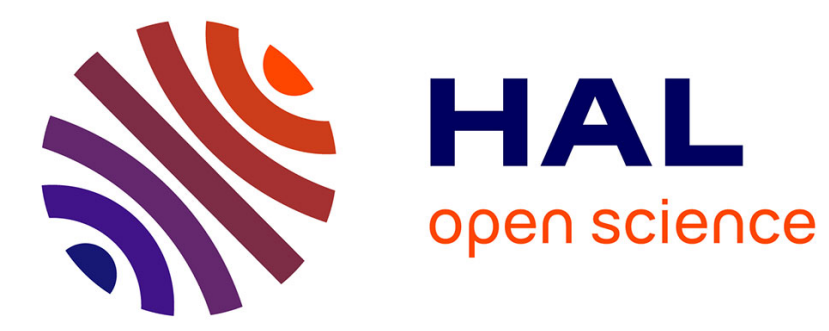

\title{
Deformation and hydration of the lithospheric mantle beneath the Kaapvaal craton, South Africa
}

Virginie Baptiste, Andrea Tommasi, Sylvie Demouchy

\section{To cite this version:}

Virginie Baptiste, Andrea Tommasi, Sylvie Demouchy. Deformation and hydration of the lithospheric mantle beneath the Kaapvaal craton, South Africa. Lithos, 2012, 149, pp.31-50. 10.1016/j.lithos.2012.05.001 . hal-00750328

\section{HAL Id: hal-00750328 \\ https://hal.science/hal-00750328}

Submitted on 29 Oct 2021

HAL is a multi-disciplinary open access archive for the deposit and dissemination of scientific research documents, whether they are published or not. The documents may come from teaching and research institutions in France or abroad, or from public or private research centers.
L'archive ouverte pluridisciplinaire HAL, est destinée au dépôt et à la diffusion de documents scientifiques de niveau recherche, publiés ou non, émanant des établissements d'enseignement et de recherche français ou étrangers, des laboratoires publics ou privés. 


\title{
Deformation and hydration of the lithospheric mantle beneath the Kaapvaal craton, South Africa
}

\author{
Virginie Baptiste*, Andréa Tommasi, Sylvie Demouchy \\ Géosciences Montpellier, Université Montpellier 2 E' CNRS, CC 60, Place E. Bataillon, 34095 Montpellier cedex 5, France
}

\begin{abstract}
To constrain the relations between deformation and metasomatism in the subcratonic lithospheric mantle, we have analyzed the microstructures and crystal preferred orientations in 50 mantle xenoliths from the Kaapvaal craton. Water contents in olivine and pyroxenes were measured in 14 samples equilibrated at different depths. Coarse-granular microstructures recording deformation by dislocation creep followed by annealing predominate. Mylonitic (sheared) peridotites with partially or totally recrystallized microstructures are however common below $140 \mathrm{~km}$. Refractory compositions predominate, but multiple metasomatic events resulted in orthopyroxene enrichment or secondary crystallization of clinopyroxene and phlogopite. Coherent orthopyroxene and olivine CPO in most coarse-grained peridotites implies in pre- to synkinematic orthopyroxene enrichment or epitaxial growth on primary orthopyroxene. Undeformed, interstitial orthopyroxene, clinopyroxene, and phlogopite with random orientations in coarse-grained peridotites record post-kinematic modal metasomatic events. Deformation of these phases in the sheared peridotites implies that mylonitization results from a later event, which affected locally the deep cratonic lithosphere. Olivine CPO recording dominant [100] glide predominate at all depths. Only two samples, equilibrated at $\sim 3.3 \mathrm{GPa}$ show olivine [001] and orthopyroxene [001] axes subparallel, suggesting dominant [001] glide. Water contents in olivine are maximum $\left(150 \mathrm{wt} . \mathrm{ppm}_{2} \mathrm{O}\right)$ in peridotites equilibrated at $\sim 160 \mathrm{~km}$ depth. Peridotites equilibrated below $180 \mathrm{~km}$ depth are, in contrast, almost dry. Lack of correlation between olivine mg\# and water content indicates that the high water contents in olivine record re-hydration after the extensive partial melting, which produced the cratonic root. The vertical variation in water contents in olivine observed in the Kaapvaal peridotites may result from hydrogen addition or loss during extraction by the kimberlites. Comparison with magnetotelluric electrical conductivity data suggests, however, that the observed vertical variation of water contents in olivine may be representative of the present-day state of the Kaapvaal mantle, implying that extensive metasomatism resulted in hydration of the cratonic mantle at intermediate depths. The annealed microstructures of Kaapvaal peridotites indicate however that this metasomatism was not followed by remobilization of the cratonic root.
\end{abstract}

\section{Introduction}

Cratons are domains of thick lithosphere with cold geotherms (Boyd et al., 1985; Chevrot and Zhao, 2007; Evans et al., 2011; Jaupart and Mareschal, 1999), which have remained stable for long geologic periods since their formation in the Archean (Pearson et al., 1995). However, while the mantle roots of some cratons, such as the Kaapvaal in South Africa, survived from reworking by plate tectonics and mantle convection since the Archean, others, like the north China and Wyoming craton, were partially destroyed in more recent times (e.g., Eggler and Furlong, 1991; Menzies et al., 1993). The processes that result in the stability or destruction of the cratonic

\footnotetext{
* Corresponding author. Tel.: + 33 467144912; fax: + 33467143603. E-mail address: virginie.baptiste@gm.univ-montp2.fr (V. Baptiste).
}

mantle roots are poorly constrained, and are a major open question in geodynamics.

Studies of kimberlite-embedded xenoliths reveal that most cratonic peridotites are depleted in $\mathrm{CaO}$ and $\mathrm{Al}_{2} \mathrm{O}_{3}$ and have olivine with high $\mathrm{mg} \#(\mathrm{mg} \#=\mathrm{MgO} /(\mathrm{MgO}+\mathrm{FeO}))$, implying that they were formed by a high degree of partial melting (e.g., Boyd and Mertzman, 1987). These observations led Jordan (1978) to propose the isopycnic (equal density) hypothesis to explain the stability of craton roots: the more refractory composition of the sub-cratonic mantle compensates the increase in density linked to cooling, implying a neutral buoyancy with respect to the asthenosphere. However, numerical models show that buoyancy alone is unable to explain the stability of cratons over several Ga (Doin et al., 1997; Lenardic and Moresi, 1999). The most common explanation for cratonic root longevity is a high viscosity contrast with the surrounding mantle (Doin et al., 1997; Pollack, 1986). The stability of cratonic roots is also favored by higher yield stresses relative to the 
surrounding lithosphere and by neighboring weak material, such as mobile belts, which may localize the deformation (Lenardic et al., 2003).

The stability of cratonic roots appears therefore to depend essentially on its rheological properties. As the dominant phase $(\geq 50 \%$ in volume), olivine controls these properties. The strength of olivinerich rocks under upper mantle conditions depends strongly on stress, temperature, grain size, and water fugacity (e.g., Demouchy et al., 2009; Hirth and Kohlstedt, 2003) and, on a lesser extent, on pressure, chemical composition, and oxygen fugacity (e.g., Keefner et al., 2011; Raterron et al., 2007). The relatively cold cratonic geotherm results in a viscosity increase of the cratonic root relatively to the surrounding convective mantle, but it cannot generate the 2-3 orders of magnitude viscosity contrast mantle required to ensure craton stability over Gy time spans (Doin et al., 1997; Lenardic and Moresi, 1999). Based on the assumption that the partial melting event responsible for the refractory compositions of cratonic xenoliths led to extensive devolatilization of the cratonic mantle, many models consider that the high viscosity of the cratonic mantle results from extremely low water concentrations in olivine (e.g., Doin et al., 1997; Pollack, 1986). However, water contents in olivine from the Kaapvaal mantle measured by Fourier transform infrared spectroscopy (FTIR) are often high (up to 100 wt.ppm $\mathrm{H}_{2} \mathrm{O}$ ), except for the deepest samples (below $180 \mathrm{~km}$ ), which have $<10$ wt.ppm $\mathrm{H}_{2} \mathrm{O}$ (Grant et al., 2007; Kurosawa et al., 1997; Peslier et al., 2010).

In the present study, we explore the relations between deformation, melt or fluid percolation, and hydration by jointly analyzing microstructures, crystallographic preferred orientations, and water contents in a new series of peridotite xenoliths of the Kaapvaal craton. Previous petrophysical studies carried out on cratonic xenoliths focused on either the relation between deformation and seismic anisotropy (Bascou et al., 2011; Ben Ismail et al., 2001) or on the water contents (Bell et al., 2004; Peslier et al., 2008, 2010; Yang et al., 2008). The association of two approaches results in additional constraints on the relative timing of deformation and hydration. For instance, experiments on olivine aggregates deformed under high water fugacities ( $>50 \mathrm{wt}$. ppm $\mathrm{H}_{2} \mathrm{O}$ ) produced olivine crystal preferred orientation patterns that differ significantly from those obtained under dry conditions; these results were interpreted as due to changes in the dominant olivine slip systems due to variations in the $\mathrm{OH}^{-}$concentration in olivine (Jung et al., 2006).

\section{Geological setting}

The Kaapvaal craton (South Africa) is an assemblage of Archean terranes that extends over more than $12,000 \mathrm{~km}^{2}$. It is mainly composed by granitoids and gneisses that enclose narrow greenstone belts, but Upper Archean and Lower Proterozoic basins cover most of it (Begg et al., 2009; de Wit et al., 1992). Crustal formation occurred essentially between $\sim 3.7$ and $\sim 3.1 \mathrm{Ga}$, followed by terrane assembly and stabilization of the craton between 3.1 and $2.6 \mathrm{Ga}$ (de Wit et al., 1992; Griffin et al., 2003).

Formation of the Kaapvaal mantle root as early as 3.3-3.5 Ga is indicated by Re-Os whole-rock data on peridotite xenoliths (Pearson et al., 1995) and on sulfides in diamond inclusions (Shirey et al., 2002). These conclusions were confirmed by Re-Os analyses of sulfide phases in peridotite xenoliths, which indicate that the Kaapvaal mantle root formed prior to $3 \mathrm{GPa}$, that is, previously to or simultaneously to the formation of the crust, implying that each terrane carried its own keel during the craton assembly (Griffin et al., 2004).

Recent electrical conductivity measurements suggest that the lithosphere beneath the central Kaapvaal craton is currently defined by a high resistivity layer 200-250 km thick (Evans et al., 2011). High seismic velocities imaged in body and Rayleigh wave tomography also indicate a $250 \mathrm{~km}$ thick root beneath most of the craton (Chevrot and Zhao, 2007; James et al., 2001). Body-wave data suggest however that the high-velocity cratonic root may locally attain depths of $300 \mathrm{~km}$ (James et al., 2001). A slightly thinner high-velocity layer, $175-250 \mathrm{~km}$ thick, was imaged recently using SH-waves (Begg et al., 2009). These lithospheric thicknesses estimated from geophysical data are slightly higher, but still consistent with the 185 to $215 \mathrm{~km}$ thick Kaapvaal lithosphere constrained by xenolith thermobarometry (Eaton et al., 2009).

Following its stabilization, the Kaapvaal craton was affected by several magmatic events. The most important is the Bushveld complex, which intruded the Kaapvaal craton at $2.05 \mathrm{Ga}$ (Scoates and Friedman, 2008). Another major magmatic event was the extrusion of the Karoo large igneous province at $182 \mathrm{Ma}$ (Riley et al., 2005), which is associated with the Gondwana breakup. The craton was also affected by numerous kimberlitic eruptions. Kimberlitic pipes were mostly emplaced between the Late Jurassic and the Cretaceous (Kramers and Smith, 1983), but also erupted between 1650 and $1200 \mathrm{Ma}$ (Kramers and Smith, 1983) and between 530 and $255 \mathrm{Ma}$ (Allsopp et al., 1985; Kramers and Smith, 1983; Phillips et al., 1998).

These kimberlitic pipes contain xenoliths of the cratonic mantle that have been extensively studied for their microstructures, petrology, and geochemistry. Kaapvaal mantle xenoliths may be classified in two groups: (1) coarse-grained peridotites, which have dominantly refractory compositions and (2) fine-grained sheared peridotites, which are equilibrated at high temperatures and pressures and have, on average, more fertile compositions (Boullier and Nicolas, 1975; Boyd and Mertzman, 1987; Boyd and Nixon, 1975; Nixon et al., 1981). Petrological and geochemical data on Kaapvaal coarse-grained nodules reveal that they represent a highly refractory lithospheric mantle residue, implying $40 \%$ melt extraction, which was subsequently affected by several metasomatic episodes (e.g., Boyd and Mertzman, 1987; Griffin et al., 2003; Kelemen et al., 1998; Nixon et al., 1981; Simon et al., 2007). The high orthopyroxene/olivine ratio that characterizes many lowtemperature Kaapvaal xenoliths, for instance, is usually attributed to Si-enrichment due to interaction with subduction-related fluids or intraplate hydrous melts (Bell et al., 2005; Kelemen et al., 1998; Simon et al., 2007; Wasch et al., 2009). Lu-Hf and Sm-Nd model ages on garnet and orthopyroxene clots in peridotite xenoliths from Kimberley suggest multiple, rather than a single Si-enrichment episode, ranging from 1.3 to $1.1 \mathrm{Ga}$ to Neoproterozoic (Wasch et al., 2009). Kaapvaal xenoliths and xenocrysts also display geochemical evidence for refertilization, which added basaltic components like $\mathrm{Fe}, \mathrm{Ca}$ and $\mathrm{Al}$ to a depleted protolith (Griffin et al., 2003). Crystallization of diopside, lherzolitic garnet, and phlogopite has been proposed to result from interactions with kimberlitic-carbonatitic fluids (Grégoire et al., 2003; Simon et al., 2007). Recent geochemical data indicate that diamonds and subcalcic garnets also result from interaction with reduced asthenospherederived fluids, corroborating the hypothesis that the cratonic mantle was originally essentially composed by highly refractory harzburgites and dunites (Malkovets et al., 2007). Melt-related metasomatism has also been identified in sheared peridotites, which may have acquired their fertile composition by interactions with asthenosphere-derived melts shortly before the kimberlitic eruption (O'Reilly and Griffin, 2010). In the present study, we will refer to all such changes in modal composition due to melt or fluid-rock interactions as modal metasomatism.

For the present study, we selected, from the $>400$ samples of the Kaapvaal mantle xenolith collection of Geosciences Montpellier (France), 50 peridotite xenoliths with varied microstructures and compositions. Study of samples from 9 pipes with ages ranging from 1.2 Ga to $87 \mathrm{Ma}$ : Kimberley, Jagersfontein, Monastery, Lentseng, De Beers, Finsch, Kamfersdam, Premier, and Mothae (Fig. 1 and Table 1), allowed the sampling of possible lateral and temporal variations of deformation and composition in the Kaapvaal mantle. Analysis of a larger number of samples from Jagersfontein and Kimberley (18 samples for each locality) allowed studying vertical variations at these locations. 


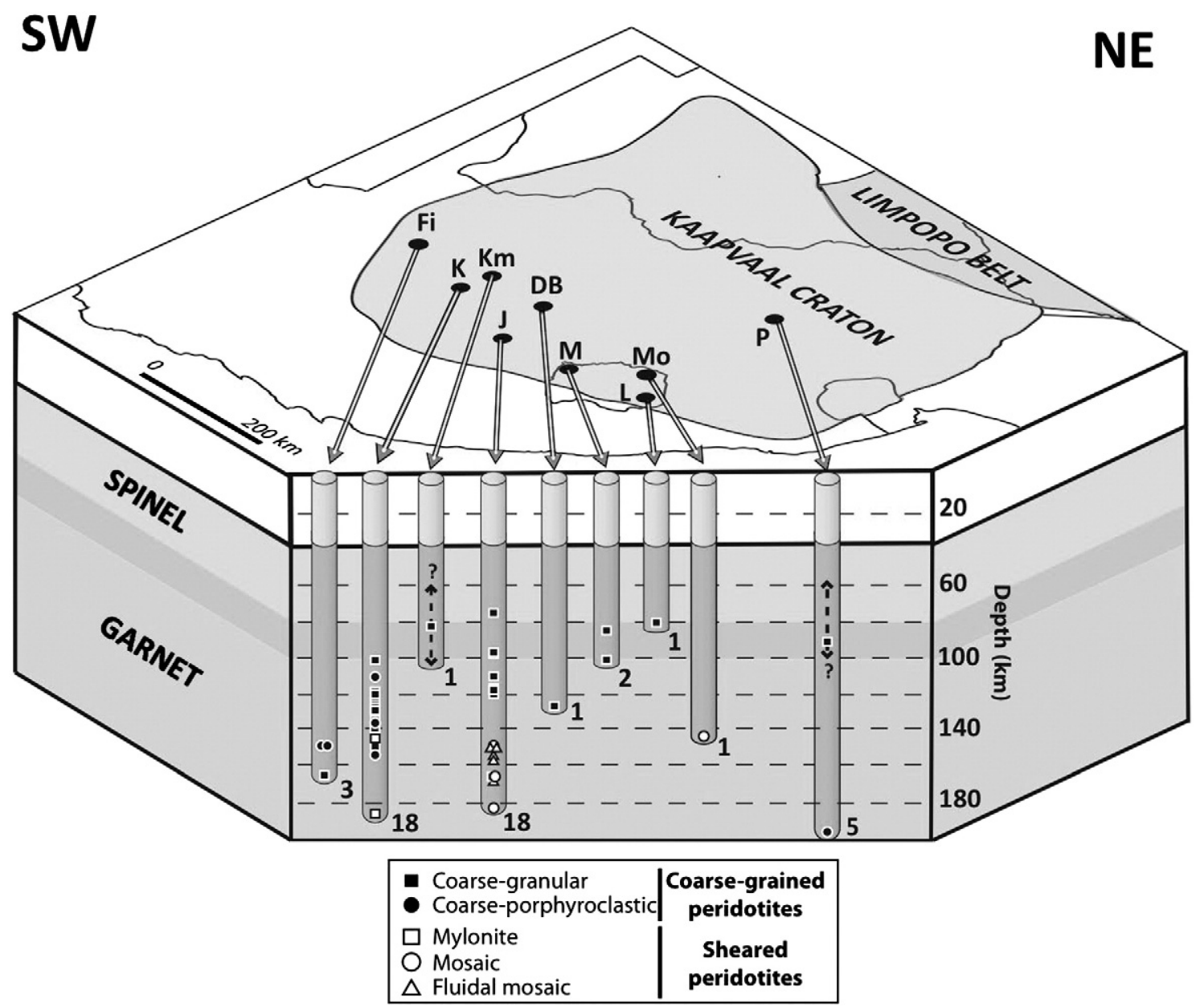

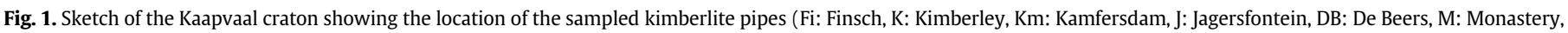

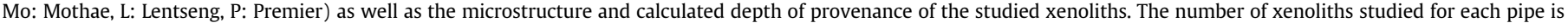
indicated at the bottom of the columns. Dark gray level indicates depths for which spinel- and garnet-bearing xenoliths are sampled.

\section{Methods}

\subsection{Mineral compositions and pressure-temperature estimates}

Chemical compositions of olivine, orthopyroxene, clinopyroxene, garnet and spinel were analyzed using a Cameca SX100 electron microprobe at Microsonde Sud facility, in Montpellier (France). Analysis conditions were a $20 \mathrm{kV}$ accelerating voltage and a $10 \mathrm{nA}$ probe current. Core and rim compositions were analyzed systematically. For each mineral phase, three to four grains were measured. The aim

Table 1

List of the studied kimberlitic pipes, the number of samples selected and their ages.

\begin{tabular}{llll}
\hline Kimberlite name & Number of samples & Age (Ma) & Reference \\
\hline Kimberley & 18 & 91 & 1 \\
Jagersfontein & 18 & 86 & 5 \\
Monastery & 2 & 90 & 1,3 \\
Lentseng & 1 & 89 & 1,4 \\
Mothae & 1 & 90 & 1 \\
Kamfersdam & 1 & 87 & 1 \\
DeBeers & 1 & 117,92 & 1,2 \\
Premier & 5 & 1202 & 4 \\
Finsch & 3 & 120 & 5 \\
\hline
\end{tabular}

1: Davis (1977).

2: Davis (1978).

3: McIntyre and Dawson (1976).

4: Kramers and Smith (1983).

5: Smith et al. (1985). was to determine pressure and temperature equilibrium conditions of the selected peridotites to constrain their depth distribution. Equilibrium temperatures were calculated using the two pyroxenes FeMg exchange geothermometer from Brey and Köhler (1990), which has an uncertainty of $\pm 30^{\circ} \mathrm{C}$. In highly-depleted garnet harzburgites that contained no clinopyroxene, the geothermometer of O'Neill and Wood (1979), based on Fe-Mg partitioning between garnet and olivine, which has uncertainties around $\pm 60^{\circ} \mathrm{C}$, was used. For garnetand clinopyroxene-free harzburgites, we used the geothermometer Li et al. (1995), based on Fe-Mg exchange between olivine and spinel, which yield temperatures within $\pm 50^{\circ} \mathrm{C}$. Equilibrium pressures were calculated using the orthopyroxene-garnet barometer of Nickel and Green (1985), which has uncertainties of $\pm 0.2 \mathrm{GPa}$. For the spinelbearing peridotites, pressures were estimated based on the equilibrium temperatures and the geotherm that best fits the equilibrium pressure and temperature data for the garnet-bearing samples.

\subsection{Electron-backscattered diffraction (EBSD)}

Crystallographic preferred orientations (CPO) of olivine, pyroxenes, and garnet in all 50 samples were measured at the SEM-EBSD facility in Geosciences Montpellier by indexation of EBSD patterns produced by interaction between an electron beam with the crystals in thin sections tilted at $70^{\circ}$ to the horizontal. Measurements were performed in a JEOL JSM 5600 scanning electron microscope using an acceleration voltage of $17 \mathrm{kV}$ and a working distance of $23 \mathrm{~mm}$. Maps covering almost entirely each thin section were performed 
using sampling steps of 100,40 or $30 \mu \mathrm{m}$, depending on grain size. Indexation rates range from 40 to $75 \%$ depending on the extent of fracturing and serpentinization in the xenolith. Phlogopite is usually poorly indexed. Indexation is also poor in very fine-grained layers in samples displaying mylonitic or fluidal mosaic textures. Orthopyroxene was rarely misindexed as clinopyroxene. Errors in the measurements were reduced by careful post-acquisition data treatment, controlled by comparison between EBSD maps and microscopic observations. Modal composition, grain sizes, and shape-preferred orientations were also obtained from EBSD maps.

Crystal-preferred orientation data is displayed in pole figures, presented as lower hemisphere stereographic projections. To avoid over-representation of large grains, data were plotted as one point per grain. When the foliation and lineation could be identified, the orientation of the main crystallographic directions: [100], [010] and [001] for olivine and pyroxenes, was plotted relatively to the principal axes of the deformation ellipsoid X, Y, and Z. However, in most coarse-grained samples, the identification of the foliation and lineation was not possible and thin sections were cut in random orientations. To allow easy comparison among different samples, we rotated the CPO of all samples into a common orientation, in which the maximum concentration of orthopyroxene [001] axes and of the olivine [010] axes are parallel to the E-W and the $\mathrm{N}-\mathrm{S}$ directions of the pole figure, respectively. This choice was based on the observation that [001] is the only known glide direction in orthopyroxene; plastic deformation tends therefore to align this axis in the flow direction (cf. review in Frets et al., 2012). This choice allowed presenting the CPO without making an ad-hoc hypothesis on the dominant glide direction in olivine. When the orthopyroxene CPO was too dispersed, the maximum concentration of olivine [100] or [001] axes, depending on which had the strongest concentration, was placed in the E-W direction of the pole figure.

The strength of the fabric was quantified using the dimensionless J-index, which is the volume-averaged integral of squared orientation densities defined by:

$J=f(g)^{2} d g$

where $f(g)$ is the orientation distribution function (ODF) and $\mathrm{dg}=\mathrm{d} \varphi_{1} \mathrm{~d} \varphi \mathrm{d} \varphi_{2} \sin \varphi \pi^{2}$, where $\varphi_{1}, \varphi$, and $\varphi_{2}$ are the Euler angles that define the rotations allowing for coincidence between the crystallographic and external reference frames. Olivine $\mathrm{CPO}$ in natural peridotites is characterized by J-indexes between 2 and 20, with a peak at 8-10 (Ben Ismaïl and Mainprice, 1998; Tommasi et al., 2000). The J-index for all samples was calculated based on the mean orientation of each grain using the Superjctf program by D. Mainprice (ftp:// www.gm.univ-montp2.fr/mainprice//CareWare_Unicef_Programs/) with a $10^{\circ}$ Gaussian half-width, $1^{\circ}$ cells, and truncation of the orientation distribution function (ODF) at $22^{\circ}$.

\subsection{Fourier transform infrared spectroscopy (FTIR)}

Fourteen doubly-polished thin sections were prepared for unpolarized FTIR analysis. Prior to analyses, all sections were immersed in pure acetone for at least $12 \mathrm{~h}$ to dissolve any intergranular CrystalBond glue. FTIR spectroscopy analyses were performed at the Laboratoire des Colloïdes, Verres, Nanomatériaux in Montpellier using a Bruker IFS66v coupled with a Bruker HYPERION microscope and a liquid nitrogen-cooled mercury-cadmium-telluride (MCT) detector. A Globar light source and a $\mathrm{Ge}-\mathrm{KBr}$ beam splitter were used to generate unpolarized mid-infrared radiation. Measurements on olivine, orthopyroxene, clinopyroxene, garnet, and phlogopite crystals were performed with square aperture sizes ranging from 40 to $100 \mu \mathrm{m}$; for each measurement 200 scans were accumulated with a resolution of $4 \mathrm{~cm}^{-1}$. They were preceded by a background measurement, followed by a baseline correction using the OPUS software, and, finally, normalized to a sample thickness of $1 \mathrm{~cm}$. Fractures and inclusions were strictly avoided. The sample thickness was measured using a micrometer with a tolerance of $\pm 1 \mu \mathrm{m}$ and was always near $500 \mu \mathrm{m}$.

The calibration of Paterson (1982) was used to quantify the $\mathrm{OH}$ concentration in each mineral phase:

$C_{O H}=\frac{X_{i}}{150 \zeta} \int \frac{k(\bar{\nu})}{(3780-\bar{\nu})} d \bar{\nu}$

where $C_{\mathrm{OH}}$ is the hydroxyl concentration (in $\mathrm{mol} \mathrm{H} / \mathrm{l}$ ), $\zeta$ is an orientation factor (1/3 for unpolarized measurements), and $K(\bar{\nu})$ is the absorption coefficient in $\mathrm{cm}^{-1}$ for a given wavenumber $\bar{\nu} . X_{i}$ is a density factor $\left(X_{i(\mathrm{ol})}=2695\right.$ ppmwt. $\mathrm{H}_{2} \mathrm{O} ; X_{i \text { (orthopyroxene) }}=$ 2812 ppmwt. $\mathrm{H}_{2} \mathrm{O} ; \quad X_{i \text { (clinopyroxene) }}=2761$ ppmwt. $\left.\mathrm{H}_{2} \mathrm{O}\right)$. Estimated errors on the resulting water contents are $\sim 30 \%$ (Kohlstedt et al., 1996). To compare the present data with previous studies where measurements were done using polarized infrared radiation and the Bell et al. (2003) calibration, $\mathrm{OH}$ concentrations for olivine have to be multiplied by a factor between 2 and 4 (Bell et al., 2003). Following Ferot (2011), a factor of 3 was used in the present study.

\section{Microstructures}

Kaapvaal xenoliths are generally highly fractured due to fast decompression during kimberlite eruption and have abundant alteration products, such as serpentine along grain boundaries and fractures. Original microstructures can however still be clearly observed. Five distinct microstructures were identified following the original classification of Boullier and Nicolas (1975). Among the 50 studied xenoliths, $78 \%$ are coarse-grained, displaying either coarsegranular (protogranular) or coarse-porphyroclastic microstructures, and $22 \%$ are fine-grained, high-temperature sheared peridotites, showing mylonitic, fluidal mosaic, or mosaic microstructures (Fig. 2).

\subsection{Coarse-grained peridotites}

Coarse-grained peridotites predominate in our xenolith suite; they are present in every studied pipe except Mothae (Fig. 1). They are characterized by plurimillimetric grain sizes (Fig. 2). Most are coarsegranular (CG) peridotites (32/50,66\%), with rare intracrystalline deformation features, but a few are coarse-porphyroclastic $(6 / 50,12 \%)$, exhibiting a well-defined foliation and lineation and frequent subgrain boundaries in olivine.

\subsubsection{Coarse-granular peridotites}

Coarse-granular peridotites correspond to the protogranular peridotites in the original Boullier and Nicolas (1975) classification, being characterized by large anhedral olivine and orthopyroxene crystals. The coarsest-grained peridotites from Jagersfontein have $\mathrm{cm}$-wide crystals (Fig. 2a). Most coarse-granular xenoliths have, however, 5$8 \mathrm{~mm}$ wide crystals in average (Fig. 2b) and a few samples have slightly smaller grain sizes (1-2 $\mathrm{mm}$ in average, Fig. 2c).

In most coarse-granular peridotites, olivine and orthopyroxene crystals have irregular shapes with curvilinear boundaries, evolving locally to polygonal arrangements with $120^{\circ}$ triple junctions (Fig. 2a-c). No foliation or lineation can be identified. However, some coarse-granular xenoliths from Kimberley have a weak foliation, highlighted by the elongation of olivine and orthopyroxene crystals (aspect ratios range from 1:2 to $1: 4$, Fig. 2b).

Olivine crystals are usually free of intracrystalline deformation, but subgrains and undulose extinctions are locally observed (white arrows in Fig. 2a-c). Orthopyroxene crystals sometimes display kinks (black arrows, Fig. 2b and c). Small interstitial orthopyroxenes are also observed; they are most often free of any intracrystalline deformation features, but may also display kinks (Fig. 3a). Clinopyroxene exsolution may or 

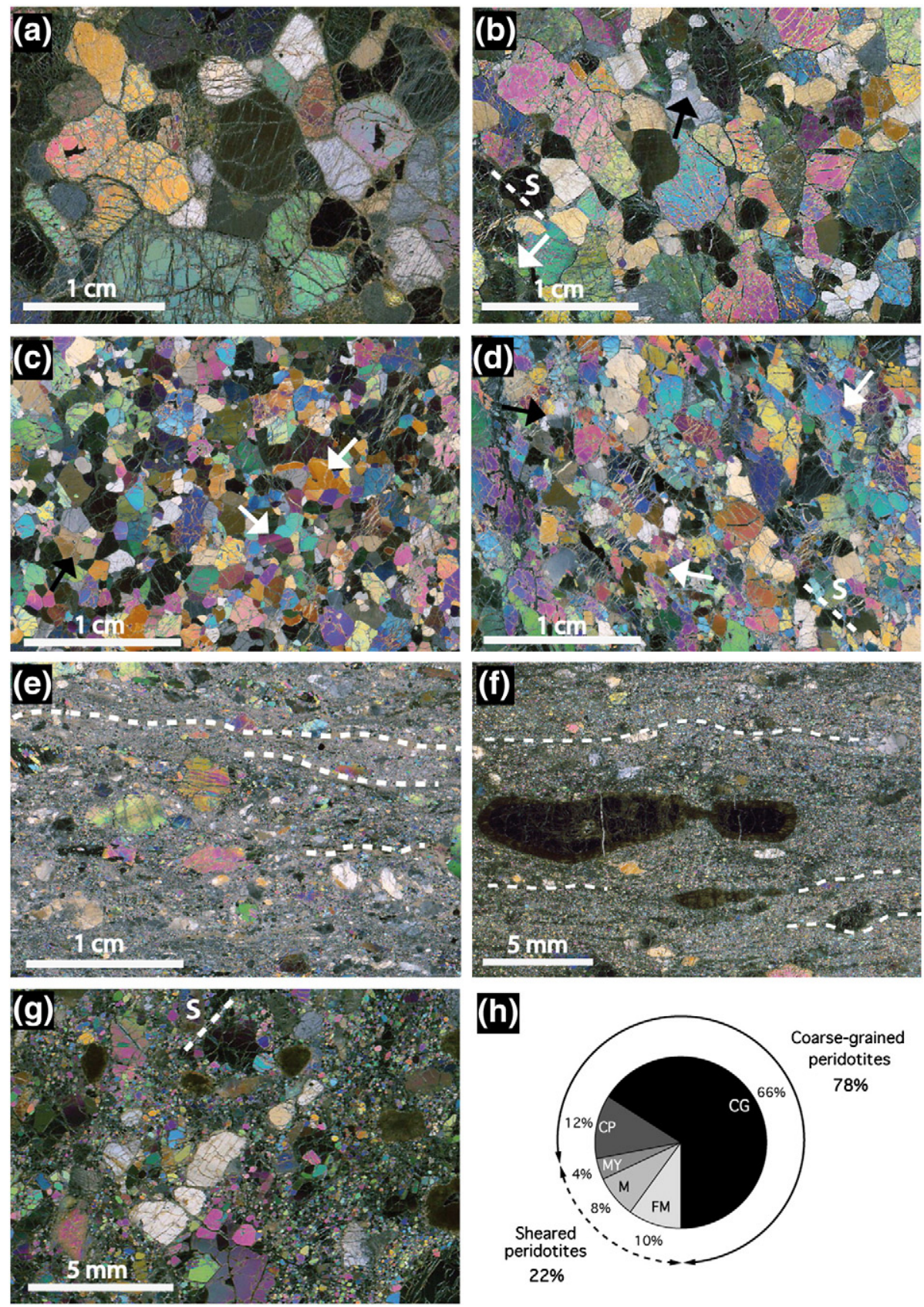

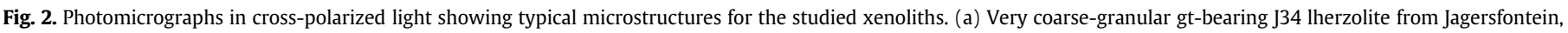

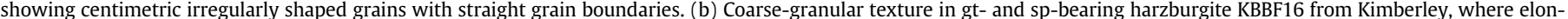

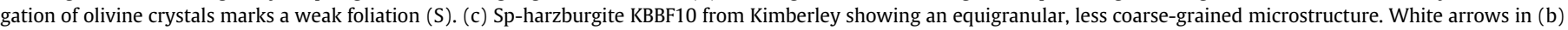

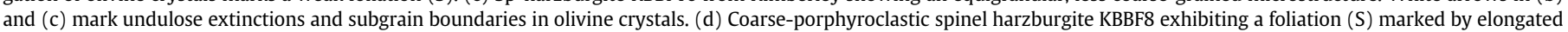

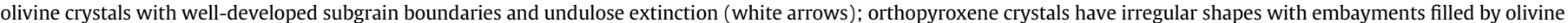

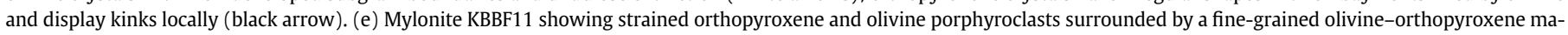

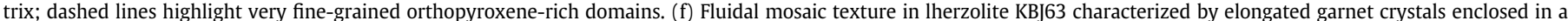

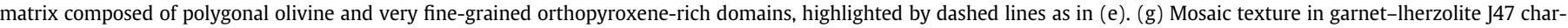

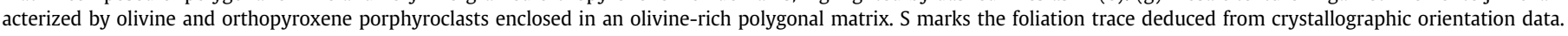
(h) Pie-chart showing the representativity of the different microstructures among the 50 studied xenoliths.

not be present. Interpenetrating boundaries between orthopyroxene and olivine grains were identified in more than half of the studied samples (Fig. 2a and b). Rounded olivine crystals are occasionally included in orthopyroxene, but orthopyroxene inclusions in olivine are also observed. Large, often undeformed clinopyroxene crystals are observed in some samples. Most clinopyroxene occurs however as small dark green crystals along vein-like structures or as small interstitial crystals. It is often spatially related to phlogopite (Fig. 3b), spinel, and garnet.
When present, garnet forms large rounded 1 to $5 \mathrm{~mm}$ wide crystals (Fig. 2b). Garnet rimming orthopyroxene is however observed in lherzolite FRB1339 from Premier (Fig. 3c). Kelyphite rims with variable thickness ( 0.06 to $1 \mathrm{~mm}$ ) are almost always present. When present, spinel occurs as dark, irregularly shaped and mm-sized crystals, as small crystals in kelyphite rims, or as small interstitial crystals along fractures and grain boundaries. Spinel-pyroxene symplectites are observed in two harzburgites. Garnet- and spinel-bearing harzburgite J41 has 

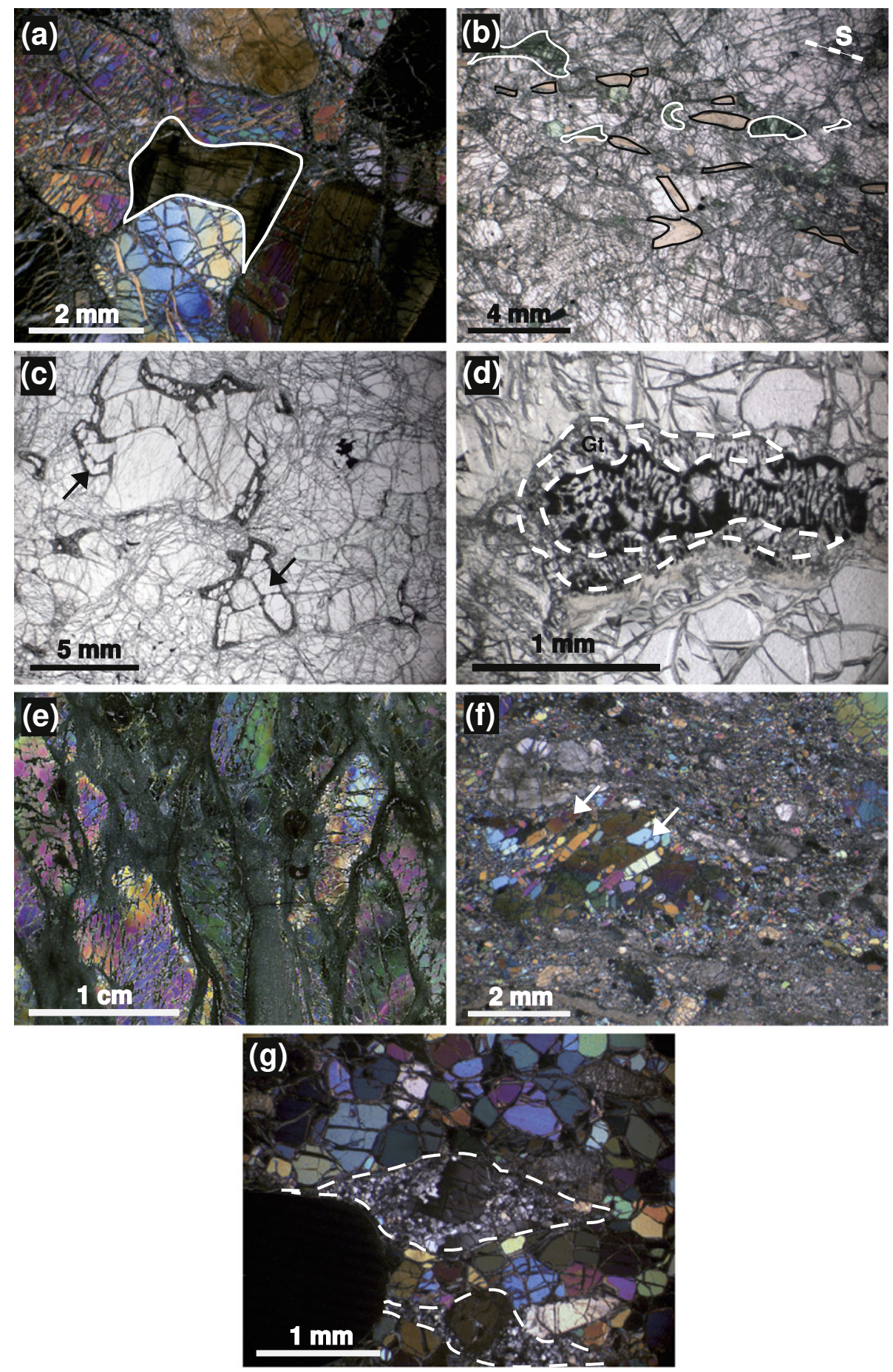

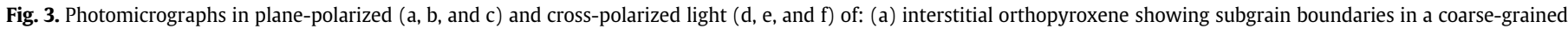

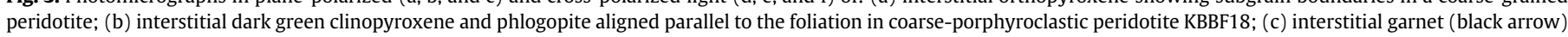

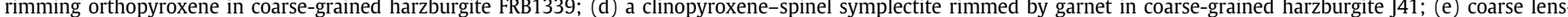

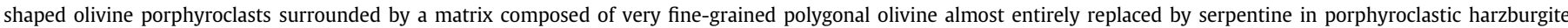

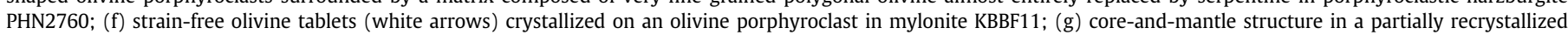
orthopyroxene porphyroclast (delimited by the dashed lines) and coarser-grained polygonal strain-free olivine neoblasts in fluidal mosaic peridotite KBJ33.

spinel-clinopyroxene symplectites rimmed by garnet (Fig. 3d), whereas harzburgite KBBF10 has spinel-orthopyroxene symplectites.

Phlogopite crystallizes as reaction products in kelyphite rims, along fractures, or as small interstitial crystals along grain boundaries or triple junctions. Millimetric to plurimillimetric, subhedral phlogopite crystals are observed in two samples (KBJ59 and KBBF14, Table 2). Among these samples, garnet- and spinel-bearing lherzolite KBJ59 from Jagersfontein displays an extremely high phlogopite content (14\%).

\subsubsection{Coarse-porphyroclastic peridotites}

Coarse-porphyroclastic microstructures are rarer, but they are observed in 6 harzburgites and lherzolites from the Kimberley, Finsch and Premier pipes, which display equilibrium temperatures ranging from $850{ }^{\circ} \mathrm{C}$ to $1464{ }^{\circ} \mathrm{C}$ (Table 2). These peridotites have plurimillimetric, lens-shaped olivine crystals (with aspect ratios up to $4: 1$ ) marking the foliation and the lineation (Fig. 2d). Olivine crystals usually exhibit undulose extinction and subgrains (white arrows 
Table 2

Textures, equilibrium conditions, modal contents, olivine mg\#, olivine CPO, olivine and opx J-indexes of the studied Kaapvaal peridotites.

\begin{tabular}{|c|c|c|c|c|c|c|c|c|c|c|c|c|c|c|c|}
\hline \multirow[t]{2}{*}{ Texture } & \multirow[t]{2}{*}{ Locality } & \multirow[t]{2}{*}{ Sample } & \multirow{2}{*}{$\begin{array}{l}\text { Pressure } \\
(\mathrm{GPa})\end{array}$} & \multirow{2}{*}{$\begin{array}{l}\text { Temperature } \\
\left({ }^{\circ} \mathrm{C}\right)\end{array}$} & \multirow{2}{*}{$\begin{array}{l}\text { Ol mg\# } \\
(\%)\end{array}$} & \multirow{2}{*}{$\begin{array}{l}\text { Reference } \\
\text { for mg\#, T, } \\
\text { and P data }\end{array}$} & \multicolumn{6}{|c|}{ Modal compositions $^{\S}$} & \multirow{2}{*}{$\begin{array}{l}\text { Olivine } \\
\mathrm{CPO}\end{array}$} & \multirow{2}{*}{$\frac{\text { Olivine }}{\text { J-index }}$} & \multirow{2}{*}{$\frac{\text { Opx }}{\text { J-index }}$} \\
\hline & & & & & & & ol & opx & $\operatorname{cpx}$ & gt & $\mathrm{sp}$ & phl & & & \\
\hline \multirow[t]{32}{*}{ CG } & Kimberley & KBBF6a & $3.8^{(3)}$ & $926^{(1)}$ & 90.8 & This study & 74 & 13 & 4 & 9 & 0 & 0 & Axial [100] & 7.6 & 9.9 \\
\hline & Kimberley & KBBF6b & $3.7^{(3)}$ & $908^{(1)}$ & 91.0 & This study & 82 & 8 & 4 & 6 & 0 & 0 & Axial [100] & 7.0 & - \\
\hline & Kimberley & KBBF9 & $4.7^{(3)}$ & $1102^{(1)}$ & 89.8 & This study & 67 & 16 & 9 & 8 & 0 & 0 & Axial [010] & 3.6 & 7.5 \\
\hline & Kimberley & KBBF10 & - & $948^{(1)}$ & 92.4 & This study & 72 & 27 & 1 & 0 & 0 & 0 & Axial [010] & 4.7 & 2.4 \\
\hline & Kimberley & KBBF14 & - & $996^{(1)}$ & 93.0 & This study & 82 & 16 & 1 & 0 & 0 & 1 & Ortho & 4.0 & 6.1 \\
\hline & Kimberley & KBBF15 & $4.3^{(3)}$ & $1067^{(1)}$ & 92.6 & This study & 65 & 31 & 0 & 4 & 0 & 0 & Ortho & 4.0 & 5.6 \\
\hline & Kimberley & KBBF16 & $4.0^{(3)}$ & - & 93.3 & $\mathrm{BI}$ & 71 & 26 & 0 & 3 & 0 & 0 & Ortho & 3.0 & 4.1 \\
\hline & Kimberley & KBBF20 & - & $800^{(1)}$ & - & $\mathrm{BI}$ & 65 & 35 & 0 & 0 & 0 & 0 & Ortho & 10.2 & - \\
\hline & Kimberley & FRB1404 & $4.4^{(2)}$ & $987^{(2)}$ & 93.5 & $\mathrm{~J}$ & 59 & 36 & 1 & 4 & 0 & 0 & Ortho & 3.5 & 6.2 \\
\hline & Kimberley & FRB1422 & $4.4^{(2)}$ & $994^{(2)}$ & 93.5 & $\mathrm{~J}$ & 65 & 31 & 0 & 4 & 0 & 0 & Ortho & 2.1 & 8.7 \\
\hline & Kimberley & FRB1423 & $3.8^{(1)}$ & $851^{(1)}$ & 91.8 & $\mathrm{~J}$ & 68 & 18 & 4 & 10 & 0 & 0 & Axial [100] & 5.5 & 10.6 \\
\hline & Kimberley & FRB1447 & $4.2^{(2)}$ & $968^{(2)}$ & 93.4 & $\mathrm{~J}$ & 73 & 23 & 1 & 3 & 0 & 0 & Axial [010] & 2.4 & 7.8 \\
\hline & Kimberley & FRB348 & $3.7^{(1)}$ & $938^{(1)}$ & 92.3 & $\mathrm{~J}$ & 58 & 28 & 7 & 7 & 0 & 0 & Ortho & 4.7 & 8.2 \\
\hline & Jagersfontein & KBJ50 & - & - & 92.2 & This study & 76 & 0 & 16 & 1 & 1 & 6 & Ortho & - & - \\
\hline & Jagersfontein & KBJ52 & - & $900^{(4)}$ & 92.7 & This study & 75 & 25 & 0 & 0 & 0 & 0 & Ortho & 4.3 & 5.7 \\
\hline & Jagersfontein & KBJ54 & $3.8^{(3)}$ & $907^{(4)}$ & 92.3 & This study & 75 & 23 & 2 & 0 & 0 & 0 & Axial [010] & 8.7 & 7.0 \\
\hline & Jagersfontein & KBJ56 & $3.5^{(3)}$ & $895^{(2)}$ & 92.5 & This study & 65 & 28 & 0 & 7 & 0 & 0 & Axial [010] & 3.8 & 7.0 \\
\hline & Jagersfontein & KBJ59 & - & $898^{(1)}$ & 89.9 & This study & 66 & 16 & 4 & 0 & 0 & 14 & Ortho & 1.5 & 4.8 \\
\hline & Jagersfontein & KBJ62 & $3.1^{(3)}$ & $759^{(2)}$ & 92.6 & This study & 64 & 36 & 0 & 0 & 0 & 0 & Ortho & 10.6 & 10.4 \\
\hline & Jagersfontein & $\mathrm{J} 34$ & $2.4^{(3)}$ & $656^{(1)}$ & 92.0 & This study & 59 & 29 & 5 & 7 & 0 & 0 & Axial [100] & - & - \\
\hline & Jagersfontein & $\mathrm{J} 41$ & $3.7^{(3)}$ & $668^{(4)}$ & 92.4 & This study & 61 & 39 & 0 & 0 & 0 & 0 & Ortho & 5.8 & 7.9 \\
\hline & Jagersfontein & $\mathrm{J} 57$ & $3.1^{(3)}$ & $765^{(2)}$ & 92.4 & This study & 79 & 18 & 3 & 0 & 0 & 0 & Axial [100] & 8.5 & 8.2 \\
\hline & Monastery & R0M23 & $3.3^{(3)}$ & $910^{(1)}$ & 92.2 & MO & 66 & 28 & 4 & 1 & 0 & 1 & Ortho & 7.1 & - \\
\hline & Monastery & R0M69 & $2.6^{(3)}$ & $784^{(1)}$ & 92.2 & MO & 76 & 20 & 3 & 1 & 0 & 0 & Ortho & - & - \\
\hline & Lentseng & PHN4274 & $4.3^{(3)}$ & $1015^{(1)}$ & 93.1 & $\mathrm{BI}$ & 62 & 33 & 2 & 3 & 0 & 0 & Ortho & 6.1 & 7.0 \\
\hline & Kamfersdam & PHN5580 & - & $*$ & 92.6 & This study & 72 & 27 & 0 & 0 & 0 & 1 & Ortho & 7.1 & - \\
\hline & De Beers & KBB2 & $4.0^{(3)}$ & $917^{(2)}$ & 93.3 & This study & 66 & 33 & 0 & 1 & 0 & 0 & Ortho & 6.5 & 9.2 \\
\hline & Premier & FRB1330 & - & $744^{(1)}$ & 91.3 & This study & 80 & 17 & 3 & 0 & 0 & 0 & Axial [100] & 4.7 & 2.6 \\
\hline & Premier & FRB1336 & $*$ & $*$ & 88.9 & This study & 70 & 30 & 0 & 0 & 0 & 0 & Axial [010] & 4.3 & 6.7 \\
\hline & Premier & FRB1339 & $*$ & $*$ & 91.7 & This study & 71 & 18 & 8 & 3 & 0 & 0 & Axial [010] & 10.4 & - \\
\hline & Premier & PHN5266 & - & $*$ & 92.7 & This study & 70 & 26 & 4 & 0 & 0 & 0 & Ortho & 6.0 & 7.4 \\
\hline & Finsch & FRB1513 & $5.2^{(3)}$ & $1037^{(2)}$ & 92.6 & This study & 70 & 27 & 1 & 2 & 0 & 0 & Ortho & 7.0 & - \\
\hline \multirow[t]{6}{*}{$\mathrm{CP}$} & Kimberley & KBBF8 & - & $1029^{(4)}$ & 94.3 & This study & 81 & 19 & 0 & 0 & 0 & 0 & Axial [010] & 8.1 & - \\
\hline & Kimberley & KBBF18 & - & $850^{(1)}$ & 92.2 & $\mathrm{BI}$ & 75 & 17 & 6 & 0 & 0 & 2 & Axial [100] & 3.6 & 5.2 \\
\hline & Kimberley & PHN2760 & $4.9^{(3)}$ & 1053 & 93.2 & $\mathrm{BI}$ & 95 & 2 & - & 3 & - & - & Ortho & - & - \\
\hline & Premier & PHN5267 & $6.5^{(3)}$ & $1464^{(1)}$ & 91.3 & This study & 70 & 19 & 6 & 5 & 0 & 0 & Ortho & 2.3 & - \\
\hline & Finsch & FRB1501 & $4.6^{(3)}$ & $1030^{(2)}$ & 93.0 & This study & 70 & 22 & 0 & 8 & 0 & 0 & Ortho & 3.6 & 5.0 \\
\hline & Finsch & FRB1512 & $4.7^{(3)}$ & $1058^{(2)}$ & 92.0 & This study & 68 & 22 & 0 & 10 & 0 & 0 & Ortho & 3.5 & 6.9 \\
\hline \multirow[t]{5}{*}{ FM } & Jagersfontein & KBJ6 & $4.9^{(3)}$ & $1163^{(1)}$ & 90.7 & This study & 84 & 9 & 3 & 4 & 0 & 0 & Bimodal & 3.2 & 2.1 \\
\hline & Jagersfontein & KBJ8 & - & $1219^{(1)}$ & 90.9 & This study & 87 & 13 & 0 & 0 & 0 & 0 & Ortho & 4.6 & 2.4 \\
\hline & Jagersfontein & KBJ14 & $4.7^{(3)}$ & $1140^{(1)}$ & 91.3 & This study & 70 & 5 & 12 & 13 & 0 & 0 & Ortho & 2.9 & 4.7 \\
\hline & Jagersfontein & KBJ33 & $4.8^{(3)}$ & $1217^{(1)}$ & 89.3 & This study & 68 & 8 & 6 & 18 & 0 & 0 & Ortho & 4.1 & 1.6 \\
\hline & Jagersfontein & KBJ63 & $4.9^{(3)}$ & $1250^{(1)}$ & 91.3 & This study & 82 & 10 & 3 & 5 & 0 & 0 & Bimodal & 4.3 & 1.6 \\
\hline \multirow[t]{5}{*}{ M } & Jagersfontein & KBJ30 & $5.8^{(1)}$ & $1282^{(1)}$ & 89.4 & G & 63 & 11 & 11 & 15 & 0 & 0 & Bimodal & 2.3 & 4.8 \\
\hline & Jagersfontein & KBJ60 & $5.2^{(3)}$ & $1190^{(1)}$ & 91.5 & This study & 86 & 13 & 1 & 0 & 0 & 0 & Bimodal & 2.5 & 7.5 \\
\hline & Jagersfontein & $\mathrm{J} 47$ & $4.7^{(3)}$ & $1227^{(1)}$ & 90.7 & This study & 85 & 6 & 8 & 1 & 0 & 0 & Bimodal & 3.2 & 4.9 \\
\hline & Jagersfontein & $\mathrm{J} 63$ & $5.2^{(3)}$ & $1176^{(1)}$ & 87.7 & This study & 78 & 10 & 10 & 2 & 0 & 0 & Bimodal & 1.8 & 5.5 \\
\hline & Mothae & PHN1925 & $4.6^{(3)}$ & $1306^{(1)}$ & 89.9 & This study & 63 & 22 & 11 & 4 & 0 & 0 & Bimodal & 1.9 & 2.0 \\
\hline MY & Kimberley & KBBF11 & $5.9^{(2)}$ & $1159^{(2)}$ & 93.6 & $\mathrm{~B} \& \mathrm{~N}$ & 88 & 11 & 1 & 0 & 0 & 0 & Ortho & 2.7 & 1.6 \\
\hline & Kimberley & FRB1402 & $4.6^{(2)}$ & $1023^{(2)}$ & 93.2 & $\mathrm{~J}$ & 83 & 9 & 0 & 8 & 0 & 0 & Bimodal & 2.2 & 2.9 \\
\hline
\end{tabular}

${ }^{(1)}$ Brey and Köhler (1990) thermometry and barometry; ${ }^{(2)}$ O'Neill and Wood (1979) thermometry; ${ }^{(3)}$ Nickel and Green (1985) barometry; ${ }^{(4)}$ Li et al. (1995) thermometry. ${ }^{*}$ Calculation was not possible because of compositional variability leading to large variations ( $>200^{\circ}$ or $>1 \mathrm{GPa}$ ) in $\mathrm{P}$, T estimates within the sample.

§Modal compositions determined from EBSD maps.

References for P, T data: BI = Ben Ismail (1999); B\&N= Boyd and Nixon (1978); G= Grant et al. (2007); J= James et al. (2004); MO= Moore (1986).

Texture: $\mathrm{CG}=$ Coarse-grained peridotite; $\mathrm{CP}$ : Coarse-porphyroclastic; $\mathrm{E}=$ Equigranular; $\mathrm{FM}=$ Fluidal mosaic; $\mathrm{M}=\mathrm{Mosaic}$; $\mathrm{MY}=\mathrm{Mylonite}$.

CPO types: ortho $=$ orthorhombic, bimodal, axial [100] and axial [010] crystal-preferred orientations, see main text and Fig. 6 for details.

$\mathrm{J}$ indexes could not be calculated for samples in which less than 100 grains were measured.

in Fig. 2d) and have sinuous to polygonal grain boundaries (Fig. 2d). Orthopyroxene is coarse-grained and irregularly shaped. Kinks and undulose extinctions in orthopyroxene are locally observed (black arrows in Fig. 2d). Interpenetrating boundaries between orthopyroxene and olivine grains are common (Fig. 2d). As in coarse-granular peridotites, rounded olivine crystals are occasionally included in orthopyroxene, but orthopyroxene inclusions in olivine are also observed. Most coarse-porphyroclastic peridotites and harzburgites have no clinopyroxene, but lherzolite PHN5267 has anhedral clinopyroxenes, which show undulose extinctions. In contrast, sp- harzburgite KBBF18 displays an alignment of interstitial, undeformed phlogopite and clinopyroxene aggregates in the foliation (Fig. 3b). When present, spinel is elongated, marking the lineation. Garnet occurs as plurimillimetric rounded crystals.

Garnet-bearing harzburgite PHN2760 from Kimberley displays an unusual coarse, but highly strained texture. This rock has very large ( $>1 \mathrm{~cm}$ long) lens-shaped olivine crystals with well-developed undulose extinction (Fig. 3e), surrounded by a very fine-grained recrystallized olivine matrix (average grain size $<25 \mu \mathrm{m}$ ). Olivine grains in the matrix have been largely replaced by low-temperature 
serpentine, but they still preserve the original polygonal shapes. Orthopyroxene porphyroclasts are rare; they are strongly altered and generally show abundant clinopyroxene exsolutions.

\subsection{Sheared peridotites}

Sheared peridotites are characterized by a bimodal grain size distribution where rare porphyroclasts are enclosed in a fine-grained matrix (grain sizes range from tens to few hundreds of micrometers). They also usually display a well-developed foliation, but the later may be absent (mosaic microstructure). Two other microstructures: mylonitic and fluidal mosaic, may be discriminated based on the average grain size of the recrystallized matrix. In our sample set, mylonitic microstructures are only observed in two xenoliths from Kimberley, fluidal mosaic microstructures in five xenoliths from Jagersfontein, and mosaic microstructures in four samples from Jagersfontein and one from Mothae.

The mylonites display large asymmetric olivine and orthopyroxene porphyroclasts (1-5 mm long), with well-developed undulose extinctions, closely-spaced subgrain boundaries, and recrystallization tails enclosed in a fine-grained matrix composed of recrystallized olivine (30-100 $\mu \mathrm{m}$ wide) and very fine-grained $(<25 \mu \mathrm{m})$ orthopyroxenerich bands (Fig. 2e). Phlogopite often displays sigmoidal shapes and strong undulose extinction. Euhedral olivine crystals devoid of any internal deformation (tablets) commonly crystallize on olivine porphyroclasts and sometimes also on matrix crystals (Fig. 3f).

In fluidal mosaic peridotites, orthopyroxene and clinopyroxene porphyroclasts are also enclosed in a fine-grained matrix with a polygonal texture, but olivine grains in the matrix are larger (up to $0.5 \mathrm{~mm}$ wide; Fig. 2f). Olivine is usually entirely recrystallized, but rare porphyroclasts are preserved in gt- and sp-lherzolites KBJ8 and KBJ63. Orthopyroxene porphyroclasts are elongated and show asymmetric recrystallization tails composed of very fine-grained orthopyroxene with polygonal boundaries and undulose extinctions (Fig. 3g). These recrystallization tails evolve into mm-scale, orthopyroxene-rich bands within the olivine-rich matrix (Fig. 3g). Olivine crystals in the matrix are polygonal and free of any internal deformation features (Fig. 3g). Garnet forms large porphyroclasts, which may be elongated parallel to the foliation, as in mosaic fluidal peridotites KBJ63 and KBJ14 (Fig. 2f). It can also be rounded, as in samples KBJ30 and KBJ33, in which garnet is more abundant ( $>15 \%$ ).

The four studied mosaic peridotites (sp-lherzolite J47, gt- and splherzolites J63, KBJ30, KB60) are characterized by large olivine porphyroclasts with strong undulose extinctions and rare subgrain boundaries, and by irregularly-shaped orthopyroxene porphyroclasts enclosed in a polygonal olivine-rich matrix (Fig. $2 \mathrm{~g}$ ). Contrary to the previous textures, these samples show neither a clear foliation nor a compositional banding. Crystallization of olivine tablets on olivine porphyroclasts is frequent. Olivine crystals in the matrix are polygonal and free of any intracrystalline deformation features. Orthopyroxene porphyroclasts are usually surrounded by finegrained orthopyroxene neoblasts $(<25 \mu \mathrm{m})$.

\subsection{Compositions and equilibrium conditions}

Most coarse-grained peridotites are harzburgites or clinopyroxenepoor lherzolites with high modal contents of orthopyroxene ( $>20 \%$, Fig. 4). Coarse-grained lherzolites are rarer. A single very coarsegrained peridotite from Jagersfontein has a wehrlitic composition that is accompanied by enrichment in phlogopite. In contrast, half of the analyzed sheared peridotites are lherzolites with fertile compositions. Garnet modal content is highly variable (0-18\%, Table 2 ) and shows no correlation with olivine or clinopyroxene contents. Spinel, when present, is always a minor phase $(\leq 1 \%)$.

The mineral compositions of the analyzed samples are presented in the online Supplementary Material Table 1. Olivine mg\# varies

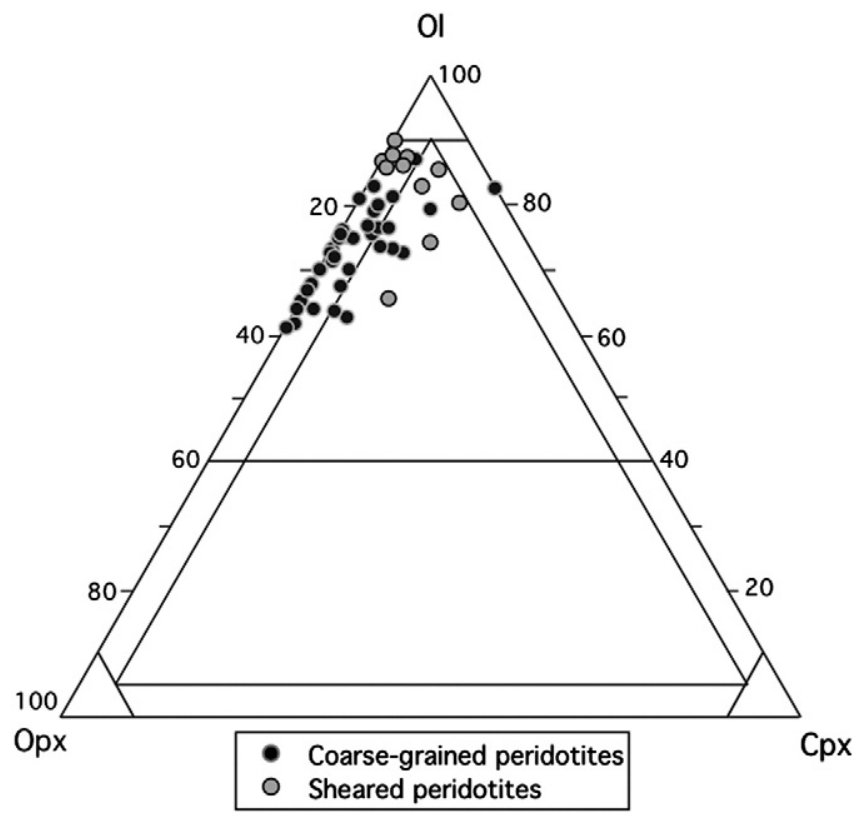

Fig. 4. Olivine:orthopyroxene:clinopyroxene modal ratios in the studied peridotites as a function of their texture. Garnet, spinel, phlogopite and serpentine were not considered for the construction of the ternary diagram; modal compositions derived from the EBSD maps were recalculated for a total of $100 \%$ of olivine + orthopyroxene + clinopyroxene.

between 87.7 and 94.3 (Table 2). Mg\# tends to be higher in coarsegrained peridotites (average mg\# 92.1) and lower in the sheared peridotites (average mg\# 91.1). However, mylonites from Kimberley are harzburgites with refractory olivines (average $m g \#=93.4$ ) and one of the lowest mg\# (88.9) pertain to olivine crystals from coarse-granular peridotite. Low mg\# in olivine are sometimes, but not always, accompanied by modal metasomatism (enrichment in clinopyroxene or phlogopite).

Orthopyroxene is enstatite; it has very low $\mathrm{Al}_{2} \mathrm{O}_{3}$ contents (<1.10 wt.\%), except for five samples (KBBF10, FRB1330, FRB1339, PHN1925, and PHN5266), where $\mathrm{Al}_{2} \mathrm{O}_{3}$ contents up to 2.76 wt.\% are observed. Orthopyroxene has also Ti-poor compositions ( $<0.30 \mathrm{wt} . \%)$. Clinopyroxene is diopside in 11 samples and augite in 14 out of 25 samples. Garnet is always pyrope-rich and is Ca-saturated except in 4 samples (FRB1336, KBJ8, KBJ50 and KBJ56). Spinel is generally $\mathrm{Cr}$-rich (cr\#>50, reaching 94 in harzburgite KBBF14). However, phlogopiterich harzburgite KBJ59 has Al-rich spinels ( $\mathrm{cr} \#=9$ ).

Coarse-grained peridotites display the widest range of equilibrium temperatures, from $650{ }^{\circ} \mathrm{C}$ to $1464{ }^{\circ} \mathrm{C}$, and pressures, from 2.4 to 6.5 GPa (Fig. 5). Equilibrium temperatures and pressures for sheared peridotites are comprised between 1023 and $1306{ }^{\circ} \mathrm{C}$ and $4.6-$ $5.9 \mathrm{GPa}$. Pressure and temperature estimates for the coarse-grained xenoliths are consistent with a geotherm leading to a surface heat flux of $40 \mathrm{~mW} / \mathrm{m}^{2}$, which intersects the $1283^{\circ} \mathrm{C}$ adiabat at $195 \mathrm{~km}$ of depth as illustrated in Fig. 5. Most sheared peridotites plot however slightly above this geotherm, in agreement with previous data for Kaapvaal sheared xenoliths (Finnerty and Boyd, 1987; Kennedy et al., 2002).

\section{Crystal-preferred orientations}

\subsection{Coarse-granular and coarse-porphyroclastic peridotites}

Coarse-granular and coarse-porphyroclastic peridotites show similar olivine $\mathrm{CPO}$ patterns, which range from orthorhombic to axial[100] or axial-[010] (Fig. 6). Orthorhombic olivine CPO predominates ( $\sim 60 \%$ of the coarse-grained peridotites). This CPO is characterized by point concentrations of the three crystallographic axes, with [100] 


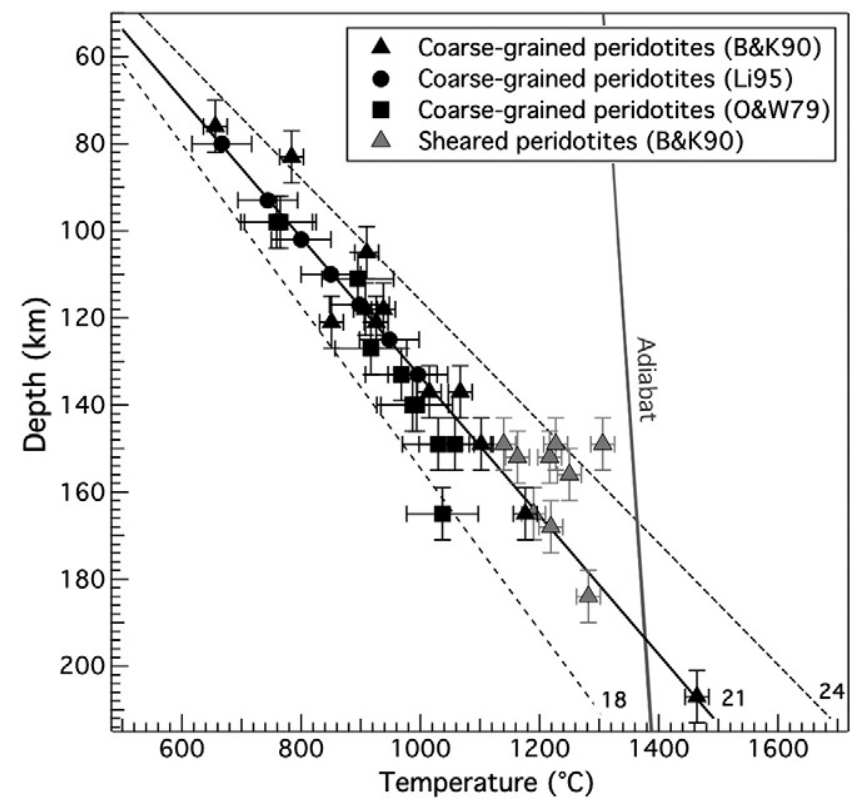

Fig. 5. Equilibrium pressures and temperatures of the studied coarse-grained and sheared peridotites (see text for details) plotted against geotherms calculated for reduced mantle heat flows of 18,20 , and $24 \mathrm{~mW} \mathrm{~m}^{-2}$. $\mathrm{T}^{\circ} \mathrm{O} \& \mathrm{~W} 79, \mathrm{~T}^{\circ} \mathrm{B} \& \mathrm{~K} 90$ and T $\mathrm{T}$ Li95 indicate data calculated using the O'Neill and Wood (1979), the Brey and Köhler (1990), and the Li et al. (1995) thermometers, respectively. Geotherms were calculated considering a crustal thickness of $35 \mathrm{~km}$ and a surface heat flow of $40 \mathrm{~mW} / \mathrm{m}^{2}$ following James et al. (2003) and Stachel et al. (2003), respectively.

axes exhibiting the strongest point concentration (Fig. 6). Seven coarse-grained harzburgites have axial-[100] CPO characterized by a strong concentration of [100] axes close to the lineation (when the latter could be determined) and a girdle distribution for [010] and [001] axes normal to the distribution of [100] axes (Fig. 6). Eight coarse-grained harzburgites have characteristic axial-[010] CPO, with a strong point concentration of [010] axes normal to the girdle distribution of [100] and [001] axes. Finally, two coarse-grained peridotites (spinel-harzburgite KBBF8, that has an axial-[010]; and garnet-harzburgite ROM 23, that has an orthorhombic olivine (PO), display a stronger concentration of [001] axes than of [100] axes (Fig. 6).

Olivine CPO intensities are highly variable. Calculated J-indexes are comprised between 1.5 and 10.6 , which correspond to very weak and to rather strong fabric, respectively (Table 2). There is no clear correlation between CPO strength and microstructure (Fig. 7a); the lowest and the highest J-index values in the present study were obtained for coarse-grained peridotites with orthorhombic olivine CPO. There is also no correlation between the olivine CPO strength and pattern (Fig. 7b) or composition (Table 2). There is, however, a relation between the olivine CPO pattern and the equilibrium pressure (Fig. 7c). Orthorhombic olivine CPOs are observed over the whole pressure range, while axial-[100] CPOs tend to concentrate on the top of the column (2.4-3.8 GPa). Axial-[010] olivine CPO are observed in xenoliths equilibrated between 3.5 and $4.7 \mathrm{GPa}$, whereas bimodal CPOs are restricted to higher pressure xenoliths, between 4.6 and $5.8 \mathrm{GPa}$.

Orthopyroxene CPO is generally more dispersed, but it is usually correlated to the olivine CPO (i.e., the main dislocation glide directions and planes, which are [100] and (010) for olivine and [001] and (100) or (010) for pyroxenes, are aligned). Orthorhombic orthopyroxene $\mathrm{CPO}$, characterized by weak point concentrations of the three main crystallographic axes, predominates. [001] axes always show the strongest concentration. In sixteen samples, [010] axes are aligned perpendicular to the plane that contain most [001] and [100] axes. In twelve other samples, [100] axes are normal to the plane containing the [001] and [010] axes. Two samples (KBBF9 and FRB1501) have, however, an axial-[001] pattern, characterized by [100] and [010] axes distributed in plane normal to the point concentration of [001] axes. Six coarse-grained harzburgites (KBBF18, FRB1404, FRB1422, FRB1423, KBJ52, J41 and J57) have an almost random orthopyroxene CPO. Three of these samples (J41, FRB1404, and FRB1422) are particularly enriched in orthopyroxene, with modal contents greater than $30 \%$. In coarse-grained peridotites PHN2760 and $\mathrm{KBJ} 50$, the number of analyzed orthopyroxene crystals is too small to identify a CPO pattern.

\subsection{Sheared peridotites}

Mylonitic, fluidal mosaic, and mosaic peridotites show weak olivine CPO; J-indexes are comprised between 1.9 and 4.6 (Fig. 7a, Table 2). Olivine CPO patterns are nevertheless well-defined, with either an orthorhombic or an axial-[010] symmetry (Fig. 6). One mylonite (KBB11) and 3 fluidal mosaic lherzolites (KBJ8, KBJ14 and KBJ33) have typical orthorhombic olivine CPO with [100] axes aligned close to the lineation and [010] axes normal to the foliation. Seven garnet-lherzolites from Jagersfontein, Kimberley and Mothae show, however, a particular axial-[010] pattern characterized by a bimodal alignment of [100] and [001] axes in the foliation plane (Fig. 6). None of the maxima are parallel to the lineation, which is underlined by the elongation of the olivine crystals and the maximum concentration of orthopyroxene [001] axes. These bimodal olivine CPO samples have systematically weak CPO (Fig. 7b). There is also a clear depth distribution: bimodal olivine $\mathrm{CPO}$ are characteristic of sheared peridotites equilibrated at pressures $>4.5 \mathrm{GPa}$ (Fig. 7c).

Orthopyroxene CPOs are weak, as indicated by J-indexes between 1.6 and 4.9. CPO patterns are nevertheless clear and correlated to the olivine $\mathrm{CPO}$, although a small obliquity $\left(<10^{\circ}\right)$ between the $\mathrm{CPO}$ of the two minerals is observed for most samples. [001] is always aligned in the lineation. In six xenoliths (mosaic peridotites KBJ60 and J47, mylonite KBFF11, fluidal mosaic peridotites KBJ33, KB14 and KBJ63), [100] axes are concentrated normal to the foliation. In four other samples (mosaic lherzolite KBJ30, mylonite FRB1402, fluidal mosaic lherzolites KBJ6 and KBJ8), [010] axes are aligned normal to the foliation, whereas [100] axes are distributed in the foliation plane and perpendicular to the lineation. Clinopyroxene CPOs (presented in the online supplementary material) are weak, but correlated to the orthopyroxene CPO in all sheared peridotites, except in mylonite FRB1402.

\section{FTIR spectroscopy and water contents}

\subsection{Olivine}

The olivine spectra of xenoliths from Kimberley are heterogeneous and complex, often displaying more than six $\mathrm{O}-\mathrm{H}$ absorption bands (Fig. 8a). This large number of absorption bands suggests $\mathrm{H}$ incorporation in a variety of point defects (e.g., Berry et al., 2007; Kovacs et al., 2010; Miller et al., 1987). A total of nine bands were identified in the studied xenoliths from Kimberley, but in most samples just a few of these bands are observed. Absorption bands can be divided into two groups: group I with absorptions between 3650 and $3450 \mathrm{~cm}^{-1}$ and group II between 3450 and $3200 \mathrm{~cm}^{-1}$ (Bai and Kohlstedt, 1993). The band at $3571 \mathrm{~cm}^{-1}$ exhibits the maximum O$\mathrm{H}$ absorbance, in agreement with observations in many natural olivines (Miller et al., 1987). The intensity of other group I absorption bands is variable. The 3610,3590 and $3525 \mathrm{~cm}^{-1}$ bands usually represent major peaks as observed for samples PHN2760 and KBBF16 spectra. Group II absorption bands have minor peaks except in sample KBBF16 where they appear to be the dominant defect sites for $\mathrm{H}^{+}$incorporation (Fig. 8a). O-H absorption bands at 3709, 3685 and $3645 \mathrm{~cm}^{-1}$ are attributed to hydrous minerals as serpentine, while 


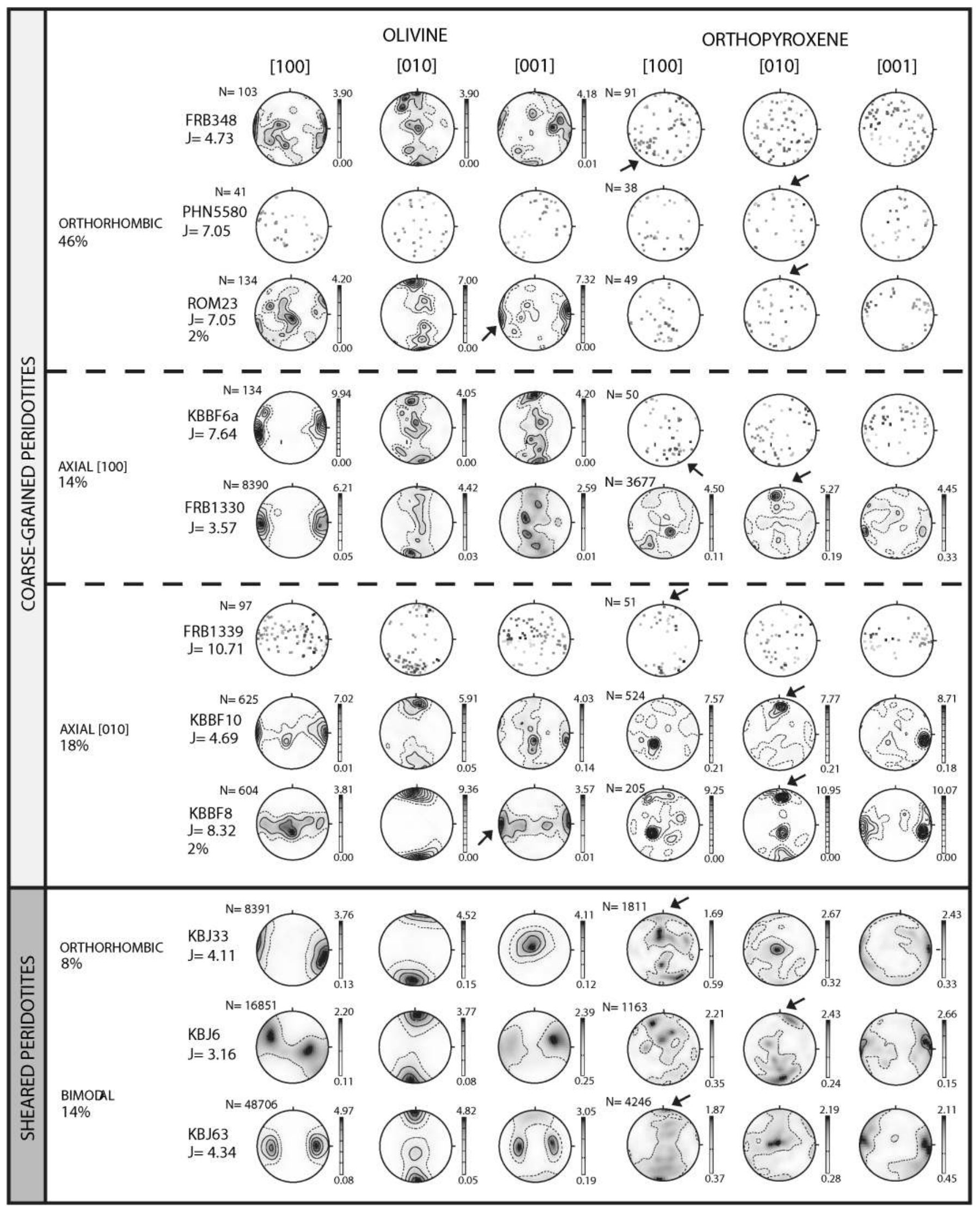

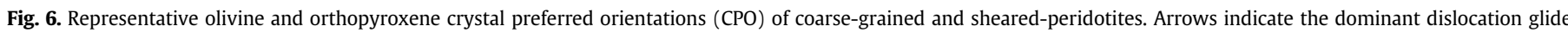

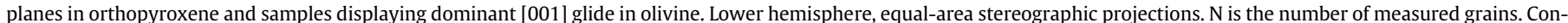
tours at 1 multiple of a uniform distribution. CPOs were not contoured when less than 100 grains could be measured. 

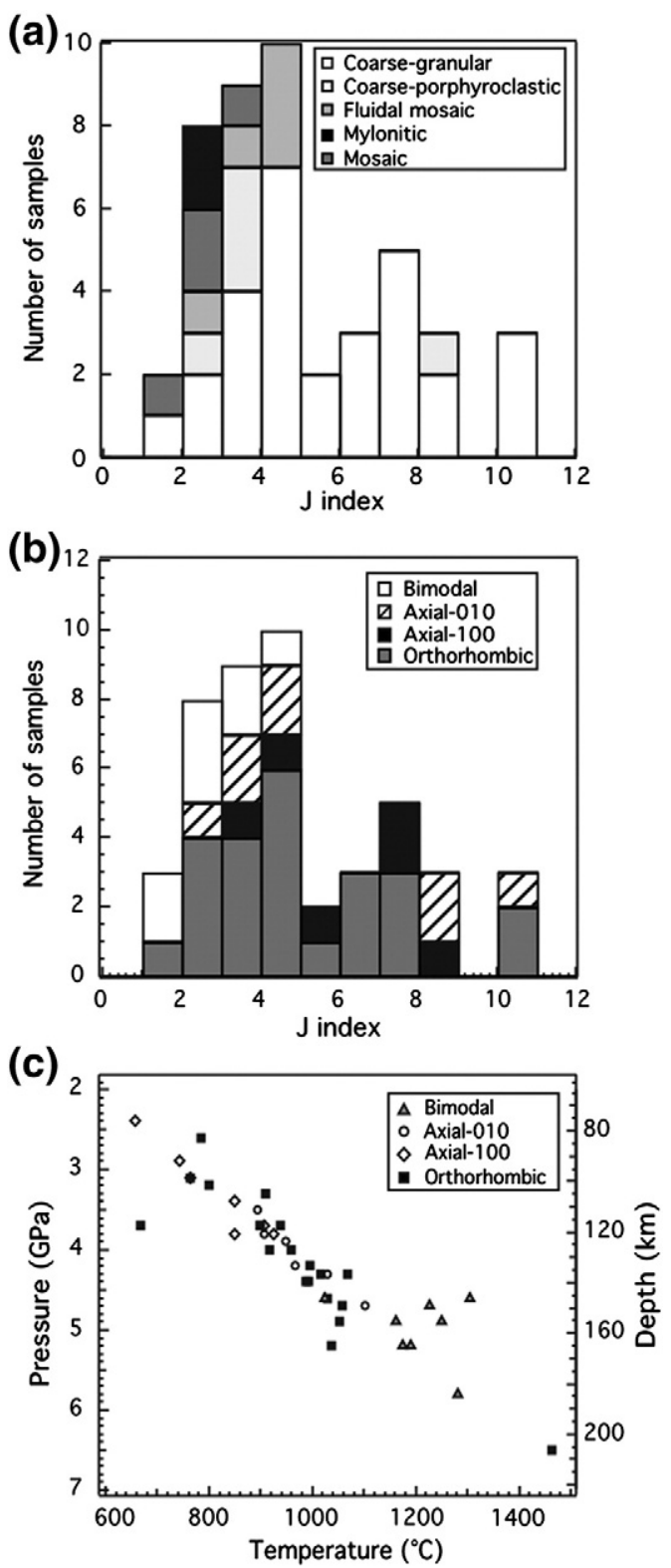

Fig. 7. (a) Olivine J-index distributions for mantle xenoliths with coarse-granular, coarse-prophyroclastic, fluidal mosaic, mylonitic, and mosaic textures. (b) Olivine Jindex as a function of the CPO symmetry. (c) Olivine CPO symmetry as a function of the equilibrium pressure and temperature of the peridotite.

the band at $3675 \mathrm{~cm}^{-1}$ is likely to be attributed to talc (Miller et al., 1987; Post and Borer, 2000).

Sample KBJ59 from Jagersfontein, which contains high modal contents of phlogopite (14\%), presents very different olivine spectra (Fig. 8a). The major peak is still located at $3571 \mathrm{~cm}^{-1}$, but important $\mathrm{O}-\mathrm{H}$ absorption bands are also present at 3598, 3571, 3525, and $3484 \mathrm{~cm}^{-1}$. Similar spectra have been described in other Kaapvaal kimberlite xenoliths from Jagersfontein, Lesotho, and Wesselton (Grant et al., 2007; Kurosawa et al., 1997).

\subsection{Pyroxenes and garnet}

Orthopyroxene spectra are more homogeneous than the olivine ones (Fig. 8b). However, most measured spectra are strongly affected by alteration, exhibiting the $\mathrm{O}-\mathrm{H}$ absorption bands at $3690 \mathrm{~cm}^{-1}$ and $3650 \mathrm{~cm}^{-1}$ usually attributed to hydrous sheet silicates (Miller et al., 1987; Skogby et al., 1990). The main absorption band associated to O$\mathrm{H}$ bonds in orthopyroxene is observed at $3600 \mathrm{~cm}^{-1}$, followed by two (a)

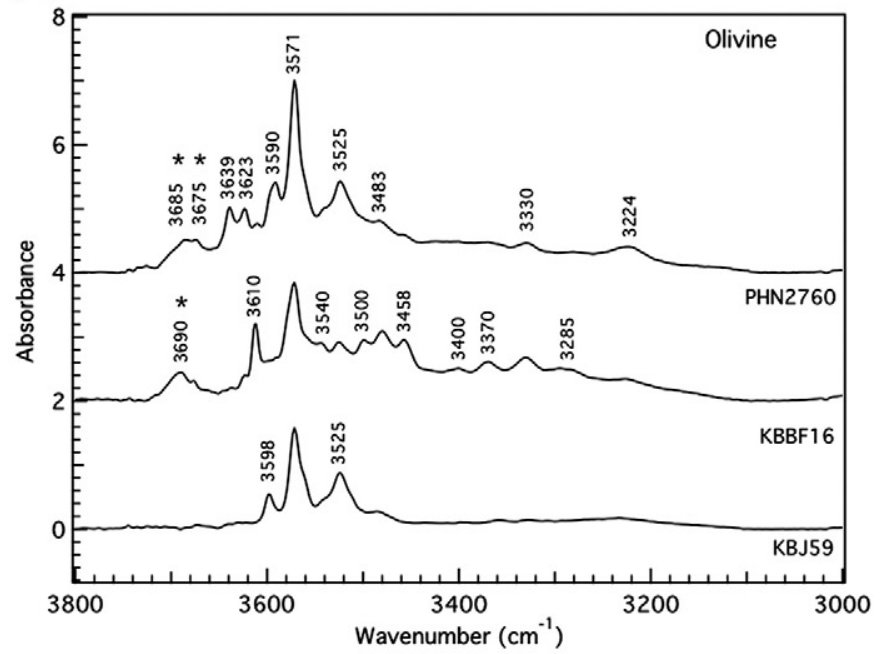

(b)
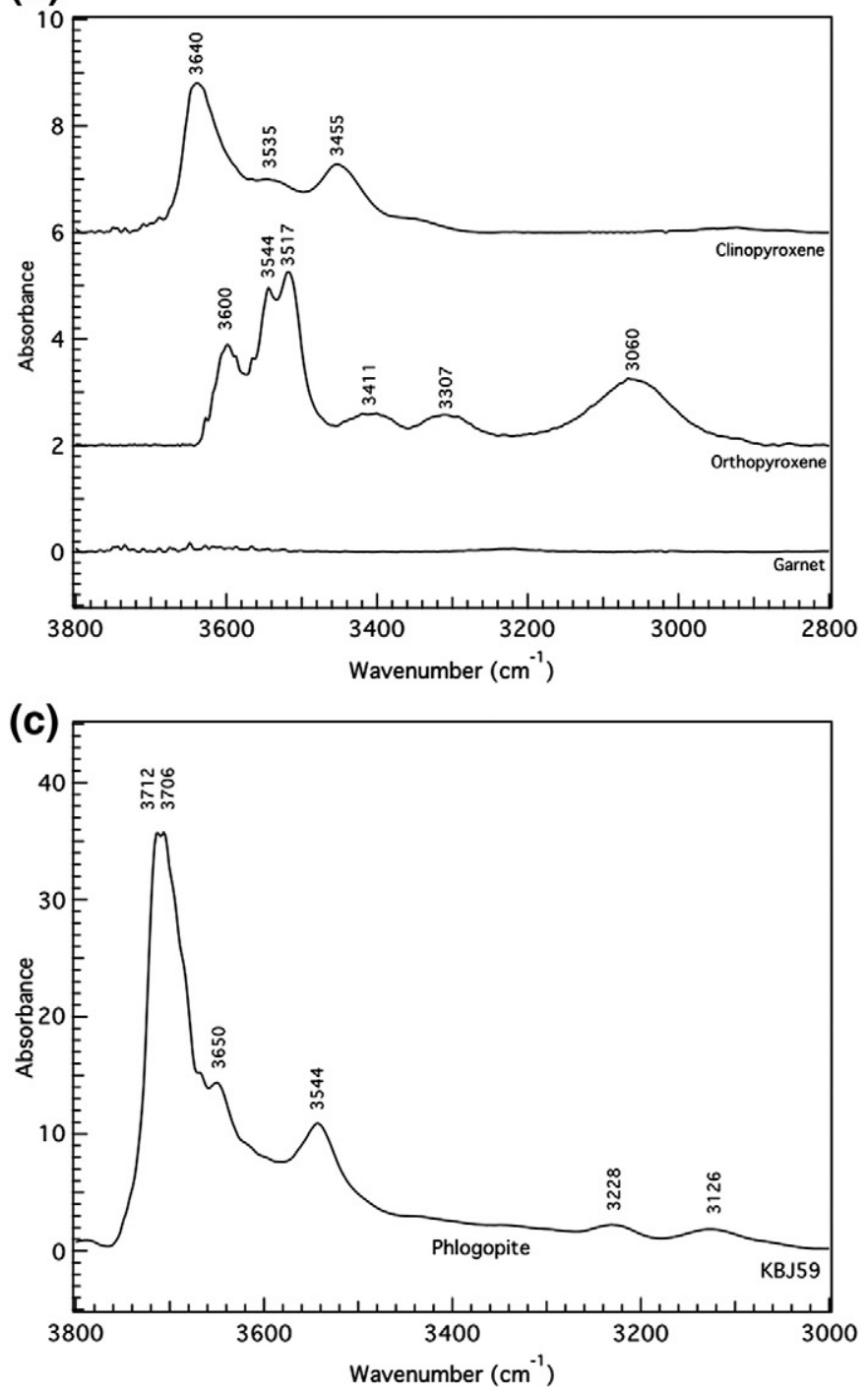

Fig. 8. Representative unpolarized infrared spectra of minerals in xenoliths from Kimberley and Jagersfontein. (a) Olivine. (b) Clinopyroxene, orthopyroxene, and garnet. (c) Phlogopite. All spectra are normalized to a sample thickness of $1 \mathrm{~cm}$. Stars indicate peaks attributed to serpentine. 


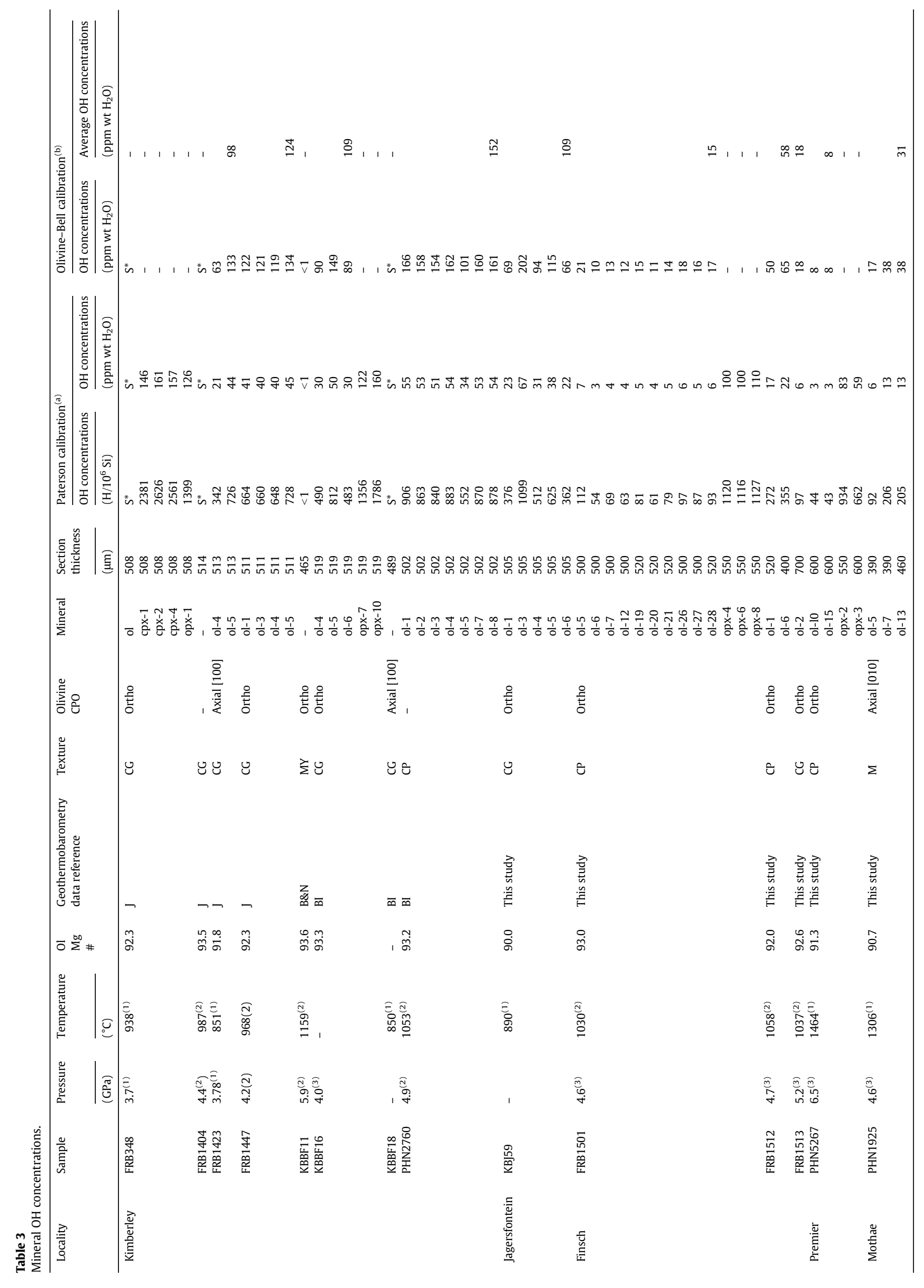


absorption bands centered at $3511-3520$ and $3559-3541 \mathrm{~cm}^{-1}$ (Fig. 8b). Broader minor peaks around 3410, 3300, and $3060 \mathrm{~cm}^{-1}$ are also observed.

Clinopyroxene spectra are homogeneous (Fig. 8b). They exhibit typical patterns for mantle-derived clinopyroxenes, with major $\mathrm{O}-\mathrm{H}$ absorption bands at 3640, 3535, and $3454 \mathrm{~cm}^{-1}$ (Grant et al., 2007; Li et al., 2008; Skogby et al., 1990). Garnet crystals were usually contaminated by serpentine and talc, displaying absorption bands 3690 , 3683 and $3675 \mathrm{~cm}^{-1}$. Spectra obtained from large, clear garnet crystals are however exempt of peaks; their spectra are flat (Fig. 8b), indicating anhydrous gt.

\subsection{Phlogopite}

Spectra in large undeformed phlogopite crystals from spinel peridotites KBBF18 and KBJ59 have three major O-H absorption bands at 3712,3706 , and $3544 \mathrm{~cm}^{-1}$ (Fig. 8c). Minor bands can be seen at 3650,3228 and $3126 \mathrm{~cm}^{-1}$. Peaks at 3712 and $3650 \mathrm{~cm}^{-1}$ are likely to be related to serpentine (Miller et al., 1987). However, an absorption band at $\sim 3706 \mathrm{~cm}^{-1}$ was previously observed in phlogopite by Miller et al. (1987).

\subsection{OH concentrations}

$\mathrm{OH}$ concentrations in olivine for each sample were calculated by averaging the $\mathrm{OH}$ concentration estimated from spectra from 2 to 7 olivine crystals in the sample (Table 3 ). $\mathrm{OH}$ concentrations in olivine could only be determined precisely for ten samples, because spectra in olivine crystals from samples KKF18, FRB348, FRB1404, and KBBF11 displayed extensive contamination by serpentine, characterized by a broad band centered at $3690 \mathrm{~cm}^{-1}$, and covering the whole range of wavenumbers for $\mathrm{O}-\mathrm{H}$ stretching bands in olivine $\left(3750-3400 \mathrm{~cm}^{-1}\right)$. Examples of serpentine-contaminated and good-quality olivine spectra are presented in Fig. 9. Water content in olivine varies between 3 and 50 wt. ppm $\mathrm{H}_{2} \mathrm{O}$ using the Paterson calibration ( 9 and 150 wt. ppm $\mathrm{H}_{2} \mathrm{O}$ after applying a conversion factor of 3 for comparison with data obtained using the Bell et al. (2003) calibration, Table 3). These values are among the highest $\mathrm{OH}$ concentrations in olivine measured in Kaapvaal xenoliths (Fig. 10). Still, higher $\mathrm{OH}$ concentrations are observed in olivine megacrysts from the Monastery kimberlite (Fig. 10).

Orthopyroxene grains are significantly more affected by alteration than olivine. Most orthopyroxene spectra exhibit some contamination by serpentine and/or amphibole, hindering an accurate determination of their $\mathrm{OH}$ concentration. However, in four samples, $\mathrm{OH}$ concentrations between 49 and 96 wt.ppm $\mathrm{H}_{2} \mathrm{O}$ could be measured (Table 3). Sample FRB348 was the only specimen where clinopyroxene spectra were free of any contamination. $\mathrm{OH}$ concentrations in those clinopyroxene vary between 146 and 161 wt.ppm $\mathrm{H}_{2} \mathrm{O}$ (Table 3).

Homogeneity in $\mathrm{OH}$ concentrations within a grain was checked by FTIR measurements along profiles with 15 or $25 \mu \mathrm{m}$ step sizes across randomly oriented olivine (in samples FRB1512 and KBJ59) and orthopyroxene crystals (in FRB1513 and FRB348). All profiles in olivine indicate homogeneous $\mathrm{OH}$ concentrations, except in the vicinity of serpentine-filled cracks and grain boundaries as illustrated in Fig. 9. These observations are in agreement with FTIR profiles in olivine from kimberlite xenoliths by Grant et al. (2007), Peslier et al. (2008), and Kamenetsky et al. (2008), which do not show any

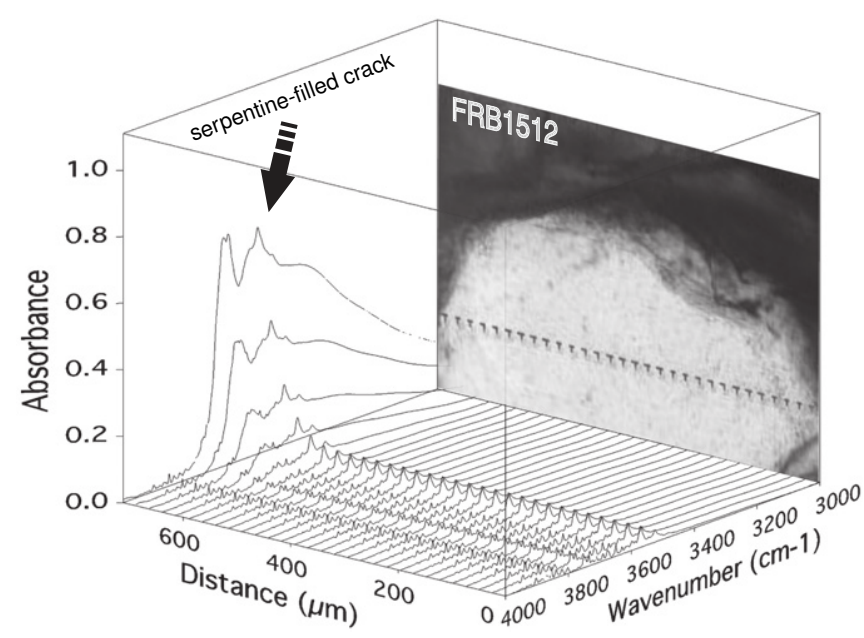

Fig. 9. Unpolarized FTIR profile along an olivine grain (random crystallographic orientation) in peridotite FRB1512. 30 spectra were measured along a $713 \mu \mathrm{m}$ long profile with a step of $24.58 \mu \mathrm{m}$ showing a homogeneous distribution before contamination by intergranular serpentine. All spectra were normalized to a sample thickness of $1 \mathrm{~cm}$.

evidence of diffusive dehydration or hydration. In orthopyroxene, contamination by serpentine and/or amphibole was too extensive that variations in water contents within a grain could not be quantified.

\section{Discussion}

The studied xenoliths represent samples of the cratonic mantle at depths ranging from $\sim 50$ to $250 \mathrm{~km}$ (Fig. 5). Extraction ages vary. Most samples come from kimberlite pipes erupted between 124 and $85 \mathrm{Ma}$, but the Premier kimberlite sampled an earlier stage of the cratonic lithosphere evolution (2000-1650 Ma, Kramers and Smith, 1983). No significant difference in deformation microstructures, $\mathrm{CPO}$, or composition is observed between xenoliths from Premier and other pipes, but one should keep in mind that only 5 xenoliths from Premier were analyzed in this study. Analysis of the microstructures allows two groups to be discriminated: coarse-grained harzburgites and sheared lherzolites, which also differ by their composition (the latter are more fertile, in average). They also display different depths of origin; sheared peridotites have systematically equilibrium pressures $\geq 4.6 \mathrm{GPa}$, whereas coarse-grained microstructures occur over the entire sampled depth range. In the following these two groups will be treated separately. First, the deformation processes and the relations between deformation, annealing, and metasomatism in coarse-grained peridotites will be discussed. Then, we will examine the mechanisms and conditions of deformation that produced the sheared peridotites and discuss their timing and origin. Finally, we discuss the implications of the water content measurements for the hydration state of the Kaapvaal craton root.

\subsection{Deformation and annealing in the coarse-grained peridotites}

Coarse-granular microstructures, characterized by plurimilimetric anhedral olivine and orthopyroxene crystals with rare intracrystalline deformation features, like subgrains in olivine or kinks in orthopyroxene

\footnotetext{
Notes to Table 3:

${ }^{(1)}$ Brey and Köhler thermometry and Barometry; ${ }^{(2)}$ O'Neill and Wood (1979) thermometry; ${ }^{(3)}$ Nickel and Green (1985) barometry.

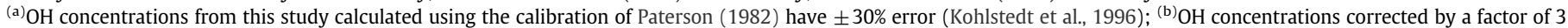
according to Bell et al. (2003).

*S = serpentine contamination prevented $\mathrm{OH}$ concentration estimations.

References: BI = Ben Ismaill (1999); B\&N: Boyd and Nixon (1978); J: James et al. (2004).

Texture: $\mathrm{CG}=$ Coarse-grained peridotite; $\mathrm{MY}=$ Mylonite.

$\mathrm{CPO}$ types: ortho $=$ orthorhombic, and axial [100] crystal-preferred orientations; see main text and Fig. 6 for details.
} 


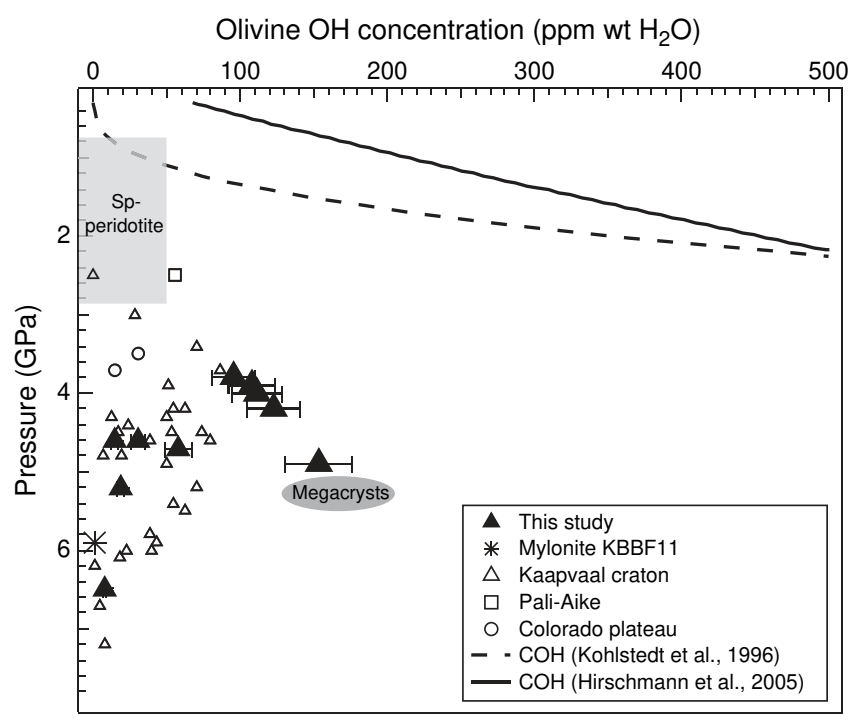

Fig. 10. OH concentration in olivine as a function of pressure in the studied xenoliths. For comparison, concentrations in olivine from previous studies on peridotite xenoliths from various cratonic and off-craton localities and in olivine megacrysts in kimberlitic magmas (Bell et al., 2004; Demouchy et al., 2006; Falus et al., 2008; Grant et al., 2007; Kurosawa et al., 1997; Li et al., 2008; Peslier and Luhr, 2006; Peslier et al., 2002; Stachel et al., 2003) are also displayed. Dashed line shows the water solubility at $1100{ }^{\circ} \mathrm{C}$ and increasing pressure from Kohlstedt et al. (1996). Solid line shows the water solubility in olivine based on Hirschmann et al. (2005).

(Fig. 2a-c), predominate among the studied garnet-bearing peridotites (66\% of the samples). This microstructure (protogranular facies of Boullier and Nicolas, 1975) has often been interpreted as undeformed. However, these peridotites show clear olivine and orthopyroxene CPO (Fig. 6), with variable strength (J-index of olivine varies from $<2$ to $>10$, Fig. 7). The clear olivine CPO, together with the curvilinear to polygonal grain boundaries that characterize these samples (Fig. 2a-c), imply that plastic deformation was followed by effective recovery and grain boundary migration under static conditions (annealing). The present study, based on a larger number of samples, therefore corroborates the early interpretation of these textures by Boullier and Nicolas (1975). The highly recovered microstructures and very coarse grain sizes displayed by these peridotites imply very effective annealing, which is not coherent with the low equilibrium temperatures recorded by these xenoliths (dominantly $<1000^{\circ} \mathrm{C}$ ). This supports an early deformation episode, perhaps associated with the formation of the cratonic root, which according to Re-Os data is older than $3 \mathrm{Ga}$ (Griffin et al., 2004), followed by a long quiescence time. Fluid-enhanced grain boundary migration during the multiple metasomatic events (Bell et al., 2005; Kelemen et al., 1998; Simon et al., 2007; Wasch et al., 2009) may also have favored annealing in the Kaapvaal mantle.

In contrast, coarse-porphyroclastic peridotites preserve welldefined intracrystalline deformation features, such as undulose extinctions and subgrain boundaries in olivine or kinks in orthopyroxene, evidencing deformation by dislocation creep. These microstructures are much less common in the analyzed xenolith collection (12\%). They correspond to domains, which may either have been less annealed because they were derived from shallower and cooler or less metasomatized parts of the mantle root, or have undergone deformation shortly before xenolith extraction. The latter interpretation is more probable for the deepest studied sample PHN5267 from Premier, which high equilibrium temperature $\left(1464^{\circ} \mathrm{C}\right)$ precludes the preservation of deformation microstructures for long times after the cessation of deformation.

Although coarse-granular microstructures are observed in all studied pipes, there are spatial differences, which were already noted by Boullier (1977). The coarsest-grained and most annealed peridotites are sampled by Jagersfontein, whereas Kimberley peridotites have finer-grained and least annealed microstructures, which preserve a weak foliation, marked by the elongation of olivine and orthopyroxene crystals (aspect ratios range from 1:2 to 1:4, Fig. 2b). Coarse-porphyroclastic microstructures are also more common in Kimberley (Table 2). This suggests either a stronger annealing or lower stress deformation in the lithospheric mantle beneath Jagersfontein. The remaining sites show, however, intermediate textures with no systematic variation.

In both coarse-granular and coarse-porphyroclastic xenoliths, the well-defined olivine CPO implies that dislocation creep was the dominant deformation process. Three olivine CPO patterns were identified: (1) axial-[100], (2) axial-[010], and (3) orthorhombic. Orthorhombic olivine CPOs are observed over the whole pressure range, while axial-[100] CPOs tend to concentrate on the top of the column (2.4-3.8 GPa). These olivine CPO patterns, characterized by a stronger concentration of [100] axes relative to [010] or [001] are coherent with simple or pure shear with dominant activation of hightemperature, low pressure, dry (010)[100] or (0kl)[100] slip systems, respectively (cf. Tommasi et al., 2000).

Axial-[010] olivine CPO, characterized by a point concentration of [010] and girdle distributions of [100] and [001] are however common in xenoliths equilibrated between 3.5 and $4.7 \mathrm{GPa}$. Such olivine CPO pattern may result from transpressional deformation (Tommasi et al., 1999), from changes in dominant glide system due to variations in physical parameters (differential stress, pressure, or water contents in olivine) during deformation, or from recrystallization (Falus et al., 2011; Tommasi et al., 2008). However, transpressional deformation should also result in dispersion of orthopyroxene [001] axes in the foliation plane, which is not observed in most studied peridotites, which show predominantly point distribution of orthopyroxene [001] axes (Fig. 6). Experimental deformation of olivine single crystals suggests that [001] glide may be favored at low temperature and high differential stresses (Durham and Goetze, 1977). The strong annealing that characterizes most coarse-grained harzburgites prevents a clear determination of the stresses and strain rates during their deformation, but their very coarse-grained microstructures is, nevertheless, more consistent with deformation under low stress conditions.

Occurrence of axial-[010] olivine CPO patterns in peridotites equilibrated at pressures 3.5-4.7 GPa might suggest that these CPO may record a change in deformation mechanism associated with an increase in confining pressure or in water contents, as the latter also increase in this depth range (Fig. 10). Experimental studies on a Griggs press (confining pressures $\sim 2 \mathrm{GPa}$ ) suggested that high water fugacities and differential stresses may induce a transition from dominant [100] to dominant [001] glide (cf. review in Jung et al., 2006). Yet, according to these experiments, the water contents in olivine measured in the present study (Table 3 ) are not high enough to induce dominant [001] glide; they rather result in the so-called E-type fabric, characterized by [100] and [001] axes aligned parallel to the lineation and normal to the foliation, respectively. The lack of clear foliation and weak CPO (supplementary online material) in the coarsegranular peridotites for which water contents in olivine could be measured in this study does not allow discrimination of which is the dominant glide plane: (010) or (001).

Transition from dominant [100] to dominant [001] glide was also observed in experimental deformation at high confining pressures (Couvy et al., 2004); the pressure at which this transition occurred varied between experiments, ranging from 3 to $3.5 \mathrm{GPa}$ (Jung et al., 2008) to $7 \mathrm{GPa}$ (Raterron et al., 2007). Equilibrium pressures for samples with axial-[010] olivine CPO (between 3.5 and $4.7 \mathrm{GPa}$ ) are in the same range as the Jung et al. (2008) values. Yet, orthorhombic olivine CPOs are even more common at these depths (Fig. 7b). Sole two samples have olivine [001] axes aligned parallel to the maximum concentration of orthopyroxene [001] axes, suggesting dominant 
[001] glide, but they are equilibrated under slightly low pressure conditions ( 3.3 GPa, Table 2).

An alternative explanation for the axial-[010] olivine CPO patterns in the coarse-grained peridotites from the Kaapvaal is dispersion of the [100] and [001] in response to recovery and subgrain rotation recrystallization (Falus et al., 2011). This interpretation is consistent with the observation that low-angle misorientations are dominantly accommodated by rotations around the [010] axis. CPO dispersion during static recrystallization may also explain the predominance of weak olivine CPO in the Kaapvaal craton (Fig. 7a). Low olivine Jindexes also predominate in peridotite xenoliths from the Siberian craton (Bascou et al., 2011). In general, cratonic peridotites yield lower J-indexes than peridotites from other tectonic settings (Fig. 11). However, although weakening of olivine CPO associated with modal metasomatism has been described in other environments (Bascou et al., 2008; Morales and Tommasi, 2011; Tommasi et al., 2004,2008 ), in the present dataset, there is no clear relation between the olivine J-index, modal contents, or olivine mg\# (Table 2).

Orthopyroxene CPOs are consistent with deformation by dislocation creep with activation of [001](100) and [001](010) slip systems. They are always correlated to olivine fabrics, meaning that both minerals underwent the same deformation. Well-defined CPOs are observed even in harzburgites showing high modal orthopyroxene, suggesting that they were deformed during or after the metasomatism leading to Si-enrichment. This interpretation is consistent with the observation of kinked interstitial orthopyroxene (Fig. 3a).

\subsection{Evidence for metasomatism and timing relative to deformation}

Textural evidence for reactive percolation of Si-rich fluids and/or melts is common in the coarse-granular harzburgites. It encompasses: (1) interpenetrating orthopyroxene and olivine boundaries (Fig. 2a-d), (2) small interstitial orthopyroxene crystals with cusped grain boundaries (Fig. 3a), (3) interstitial garnet in peridotite FRB1339 (Fig. 3d), (4) crystallization of small, interstitial, Cr-rich clinopyroxene, often associated with spinel and phlogopite (Fig. 3d), and (5) phlogopite rimming garnets or as interstitial crystals. Observation (1) may result either from orthopyroxene consumption during the extensive partial melting event that produced the most refractory olivines (Boyd and Mertzman, 1987) or from orthopyroxene crystallization at the expenses of olivine in response to reactions with Si-rich aqueous fluids or hydrous melts (Bell et al., 2005; Kelemen et al.,

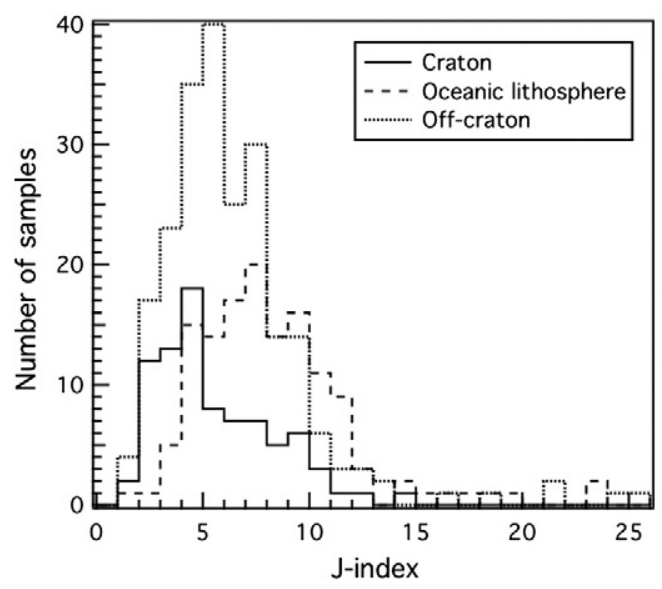

Fig. 11. Olivine J-index distributions for mantle xenoliths from cratons, off-craton continental regions, and oceanic plates. Data for cratonic samples from this study, Vauchez et al. (2005) and Bascou et al. (2011); for off-craton continental regions from Ben Ismaïl and Mainprice (1998), Vauchez and Garrido (2001), Pera et al. (2003), Duclos et al. (2005), Tommasi et al. (2006), Le Roux et al. (2007), Falus et al. (2008), Le Roux et al. (2008), Tommasi et al. (2008), Soustelle et al. (2009), and Morales and Tommasi (2011); and from oceanic plates from Ben Ismaïl and Mainprice (1998), Tommasi et al. (2004), and Soustelle et al. (2010).
1998; Wasch et al., 2009). In contrast, observation (2) points to late crystallization of orthopyroxene and is consistent with the excess modal content of orthopyroxene, which characterizes the Kaapvaal harzburgites (Bell et al., 2005). The remaining observations point to partial crystallization or reaction with percolating melts at high pressure (3) and with K-rich compositions (4 and 5).

Analysis of the microstructures may help in constraining the relative timing between deformation and episodes of reactive fluid percolation, even if some observations are ambiguous. Kinks in interstitial orthopyroxene (Fig. 3a) indicate pre- to syn-kinematic silica enrichment. However, undeformed orthopyroxenes with clear interstitial habitus are also observed in some samples, suggesting strongly that Si-enrichment may have continued post-kinematically. As discussed in the previous section, olivine and orthopyroxene CPOs are consistent, suggesting that both minerals recorded the same deformation, even in orthopyroxene-rich harzburgites, implying pre- to synkinematic metasomatism. Orthopyroxene CPO is however usually weak (the strongest values in Table 2 probably result from overestimation of the orthopyroxene $\mathrm{CPO}$ strength due to measurement of too few crystals), implying that post-kinematic orthopyroxene addition is also possible.

Phlogopite and clinopyroxene enrichment, on the other hand, is essentially post-kinematic, as indicated by the interstitial shapes and undeformed character of these minerals (Fig. 3d). The actual timing and processes responsible for this late metasomatism by $\mathrm{K}$ rich fluids or melts (Bell et al., 2005; Grégoire et al., 2003; Griffin et al., 2003), are however still unclear; it may have happened at any point between the last deformation episode and shortly before extraction by the kimberlitic magmatism. In sample KBBF18, alignment of undeformed phlogopite and clinopyroxene parallel to the foliation (Fig. 3d) suggests nevertheless that the pre-existing deformation structure may have controlled the melt infiltration.

\subsection{Sheared peridotites}

Sheared peridotites are characterized by high equilibrium temperatures (between 1000 and $1300{ }^{\circ} \mathrm{C}$ ) and relatively fertile compositions as pointed out by Nixon et al. (1981). They probably represent ancient coarse-granular rocks that underwent extensive dynamic and static recrystallization. Harzburgite PHN2760, with its very unusual texture (Fig. 4d), may indeed be an illustration of the first steps of formation of the sheared peridotites, which was followed by extensive fracturing and low-temperature serpentinization due to reaction with the kimberlitic melt during extrusion.

The asymmetry of the porphyroclasts in the mylonite implies simple shear deformation. Moreover, the fine recrystallized grain sizes indicate deformation under high deviatoric stresses and deformation rates (Austin and Evans, 2007), in particular considering the high equilibrium temperatures of these peridotites. Both orthopyroxene and olivine underwent dynamic recrystallization but the degree of recrystallization and the recrystallized grain size are larger in olivine than in orthopyroxene, consistent with the higher strength of orthopyroxene relative to olivine. Development of shear bands along fine-grained recrystallized orthopyroxene-rich layers suggests, that more effective grain refinement in the higher strength orthopyroxene-rich domains lead to strain localization. Boullier and Gueguen (1975) proposed that the olivine-rich domains deformed by dislocation creep whereas the fine-grained recrystallized orthopyroxene-rich layers deformed by grain sensitive creep.

Evidence of plastic deformation by dislocation creep, such as undulose extinction, subgrain boundaries, and recrystallization tails, has also been identified in mosaic and fluidal mosaic peridotites. However, the presence of polygonal recovered olivine crystals in the matrix implies that some annealing followed the deformation. The variable grain size and amount of polygonal crystals in the matrix may reflect different temperatures, annealing times, or variable 
influence of fluids on the annealing process. Euhedral olivine crystals free of any deformation features (usually called tablets) are commonly observed on both strained porphyroclasts and the matrix of mosaic and fluidal mosaic peridotites. Such euhedral crystals have been often described in sheared xenoliths from South Africa (e.g., Boullier and Nicolas, 1975; Drury and Van Roermund, 1989; Skemer and Karato, 2008). Drury and Van Roermund (1989) proposed that these crystals record fluid-assisted static recrystallization, where a thin fluid film along grain boundaries enhances grain boundary mobility. Fluids may also have played an essential role in the formation of the mosaic texture, which may represent a more developed stage of fluidassisted static recrystallization. The preservation of the fine-grained texture and deformation features in the orthopyroxene-rich shear bands may be explained by slower grain boundary migration in orthopyroxene in comparison to olivine (Skemer and Karato, 2008). Mosaic and fluidal mosaic peridotites may thus derive from porphyroclastic and mylonitic peridotites to which annealing is superimposed, respectively (Boullier and Nicolas, 1975).

Sheared peridotites display either orthorhombic or bimodal olivine CPO. The orthorhombic CPOs are consistent with deformation by dislocation creep activating high-temperature, low pressure (010)[100] slip system. The axial-[010] with a bimodal distribution of [100] and [001] axes suggest, on the other hand, simultaneous activation of the (010)[100] and (010)[001] slip systems. Similar olivine CPO were described in deep mantle xenoliths from the Tanzanian craton (Vauchez et al., 2005) and have been interpreted as resulting from activation of the two slip directions at high pressure and probably high stresses. This interpretation is consistent with the observation that bimodal olivine $\mathrm{CPO}$ are characteristic of sheared peridotites equilibrated at pressures $>4.5 \mathrm{GPa}$ (Fig. 7c). Olivine $\mathrm{CPO}$ strength is always low (Fig. 7a), probably due to the extensive recrystallization (Falus et al., 2011). Orthopyroxene CPOs are coherent with deformation by dislocation creep with contribution of both [001] (100) and [001] (010) slip systems. Clinopyroxene CPO is consistent with deformation by dislocation creep, with dominant activation of the [001]\{110\} systems (Bascou et al., 2002). Both pyroxenes CPOs are correlated with the olivine CPO (Fig. 6 and online supplementary material), indicating that all major rock-forming minerals underwent the deformation producing the mylonitic microstructure. Indeed, clinopyroxene occurs as strained porphyroclasts and has $\mathrm{CPO}$ coherent with the olivine and orthopyroxene, indicating pre-mylonitization refertilization. Finally, alignment of recrystallized phlogopite in the mylonitic foliation in KBBF11 indicates that the mylonitization postpones potassic metasomatism. This observation contrasts with the pre-kinematic character of phlogopite in coarse-grained harzburgites, suggesting that mylonitization corresponds to a later deformation event.

In summary, microstructures and CPO in the sheared peridotites are consistent with post-metasomatism deformation by dislocation creep under high stress and strain rates. Fluidal mosaic and mosaic microstructures may be explained by subsequent fluid-assisted static recrystallization that may be related to the kimberlitic magmatism. The processes leading to this deformation have been widely debated in the literature. The kinked geotherm obtained from thermobarometry in mantle xenoliths from the Kaapvaal made Boyd and Nixon (1975) propose that the sheared peridotites may result from localized shearing at the lithosphere-asthenosphere boundary (LAB). This interpretation was re-proposed by Kennedy et al. (2002) for the sheared peridotites of the Slave craton. However, already in the 70s, Goetze (1975) highlighted that the observed geotherm disturbance is not consistent with shear heating and that the strain rates estimated from the microstructures and equilibrium temperatures of these rocks are too high to be produced by plate tectonics. Similar conclusions were reached by Boullier (1977) and more recently by Skemer and Karato (2008). Our observations are consistent with these conclusions, favoring the model proposed by Green and Gueguen (1974), who viewed the deformation that produced the sheared peridotites as due to ascending kimberlitic diapirs, instead of a quasi-stationary mantle flow at the LAB.

\subsection{Hydration state of the Kaapvaal mantle lithosphere}

$\mathrm{OH}$ concentrations in olivine obtained in this study are highly variable, however they show a general increase with pressure up to $5 \mathrm{GPa}$ and a sharp decrease for pressures $>5.9 \mathrm{GPa}$ (Fig. 12, Table 3 ). Maximum water contents in olivine measured in this study are among the highest ones measured in mantle peridotite xenoliths, reaching values close to those measured in kimberlite-borne megacrysts (Fig. 10). In samples equilibrated at pressures higher than $5.9 \mathrm{GPa}$, reliable estimates of water contents in olivine could be obtained for two samples, one coarse-grained peridotite and a mylonite. Both show $<10$ wt.ppm $\mathrm{H}_{2} \mathrm{O}$ (Table 3), consistently with previous data in four other deep Kaapvaal peridotites by Peslier et al. (2010).

The observed increase in $\mathrm{OH}$ concentrations in olivine with depth up to $5 \mathrm{GPa}$ is consistent with the increase of water solubility with increasing $\mathrm{fH}_{2} \mathrm{O}$ and, hence, with pressure (Kohlstedt et al., 1996). Measured water contents remain, however, well below the olivine solubility curves of Hirschmann et al. (2005) and Kohlstedt et al. (1996), suggesting that even the most water-rich peridotites in the Kaapvaal are undersaturated in water. However, these water solubility curves in olivine only consider the effect of pressure. They do not include the effects of temperature, iron content in olivine, or the change of water fugacity with increasing solute dissolution at high pressures and temperatures and probably overestimate the solubility in the deepest part of the cratonic root (Bali et al., 2008; Ferot, 2011). Most analyzed peridotites contain phlogopite. Since hydrogen is compatible in sheet silicates, crystallization of phlogopite does not require prior saturation of the nominally anhydrous minerals (NAMs) that compose the peridotite. A recent experimental study shows that water solubility curves of mantle minerals are strongly modified by the presence of pargasite (Green et al., 2010). A similar behavior might be expected for olivine co-existing with phlogopite, but the solubility of water in NAMs in a phlogopite-bearing assemblage has not been quantified yet. In the present dataset, $\mathrm{OH}$ concentrations in olivine are uncorrelated with the presence or absence of phlogopite (Tables 2 and 3), although less IR peaks are observed in the phlogopite-rich sample KBJ59 (Fig. 8).

Are the measured values in olivine representative of $\mathrm{OH}$ concentrations at different depths in the Kaapvaal mantle? Since $H$ behaves

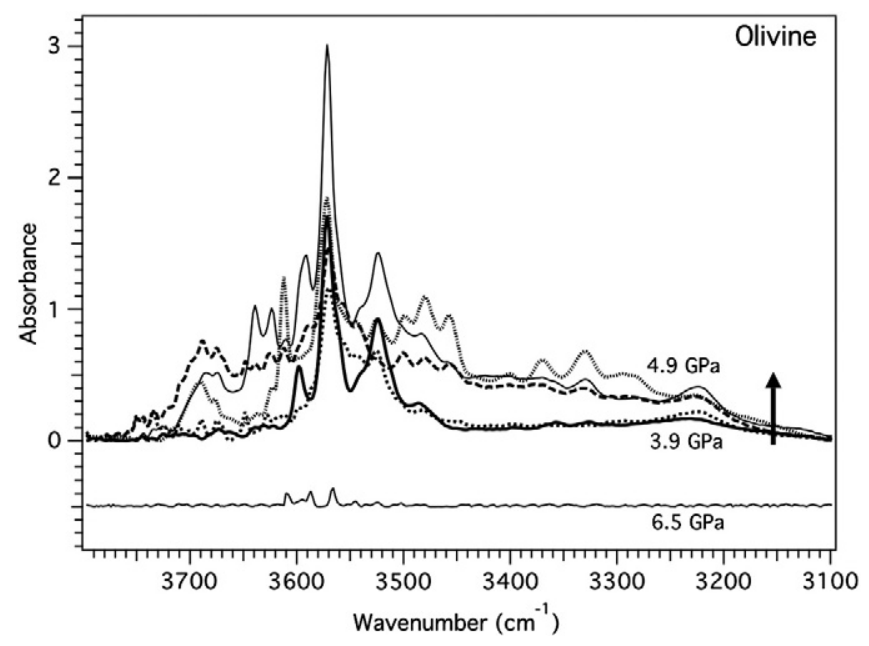

Fig. 12. Unpolarized infrared spectra of olivine showing the increase in absorbance with increasing equilibrium pressure between $3.9 \mathrm{GPa}$ and $4.9 \mathrm{GPa}$ and a spectrum from a deeper sample (PHN5267, equilibrated at $6.5 \mathrm{GPa}$ ). All spectra are normalized to a sample thickness of $1 \mathrm{~cm}$. 
as an incompatible element during partial melting (Bolfan-Casanova, 2005; Dixon et al., 2002; Hirschmann et al., 2005), olivines with high forsterite contents are expected to have low $\mathrm{OH}$ concentrations. This relation is not observed in the Kaapvaal peridotites; high $\mathrm{OH}$ concentrations were measured in olivines with mg\# ranging from 90 to 94 (Fig. 13). This implies that the high water contents in olivine from intermediate depths in the cratonic mantle record re-hydration after the main partial melting episode that produced the mantle root. This conclusion brings additional questions. When and how did this water addition occur? What is its spatial extent?

High $\mathrm{OH}$ contents in olivine may result from hydration: (A) by solid-state diffusion of hydrogen from a volatile-rich asthenosphere, (B) during transport by the volatiles-rich kimberlitic magma, or (C) during metasomatism of the craton root by water-rich fluids or melts (Fig. 14). Re-hydration of lithospheric mantle in a continuous way by solid-state diffusion of hydrogen from the asthenosphere is not consistent with the observed low $\mathrm{OH}$ contents in olivine from peridotites equilibrated at $>5.9 \mathrm{GPa}$. Moreover, even if the fast hydrogen flux along grain boundaries is taken into account (Demouchy, 2010), solid-state diffusion is a process too slow. For an average grain size of $1 \mu \mathrm{m}$, which is much smaller than even the smallest grains in the mylonites, and an effective hydrogen diffusion coefficient of $4.48 \times 10^{-8} \mathrm{~m}^{2} / \mathrm{s}$ at $1250{ }^{\circ} \mathrm{C}$ (Demouchy, 2010) more than $3 \mathrm{~Gy}$ would be needed to re-hydrate the entire cratonic root, and if a more representative grain size of $3 \mathrm{~mm}$ is considered, the $\mathrm{H}$ diffusion front would have progressed by less than $10 \mathrm{~km}$ over $3 \mathrm{~Gy}$.

Scenario (B), that is, hydration during xenolith extraction by the kimberlites, is based on the observation that olivine megacrysts from kimberlites have high $\mathrm{OH}^{-}$contents (Fig. 10), suggesting that the kimberlite magma is volatile-rich and, perhaps, water-saturated. It is also consistent with experimental data and with dehydration FTIR profiles in olivines from basalt-borne peridotite xenoliths, which both show extremely fast hydrogen diffusion in olivine at high temperature (Demouchy and Mackwell, 2006; Demouchy et al., 2006; Peslier and Luhr, 2006). Hydrogen addition to xenolithic minerals may therefore occur during the transport of the xenoliths, even if FTIR profiles do not record these exchanges (Kamenetsky et al., 2008).

In scenario (C), the re-hydration of the cratonic mantle is proposed to be associated with metasomatism by water-rich fluids or melts, for which there is abundant modal and geochemical evidence, like the Si-enrichment (Fig. 3a; Bell et al., 2005; Kelemen et al., 1998; Simon et al., 2007; Wasch et al., 2009) or the crystallization of

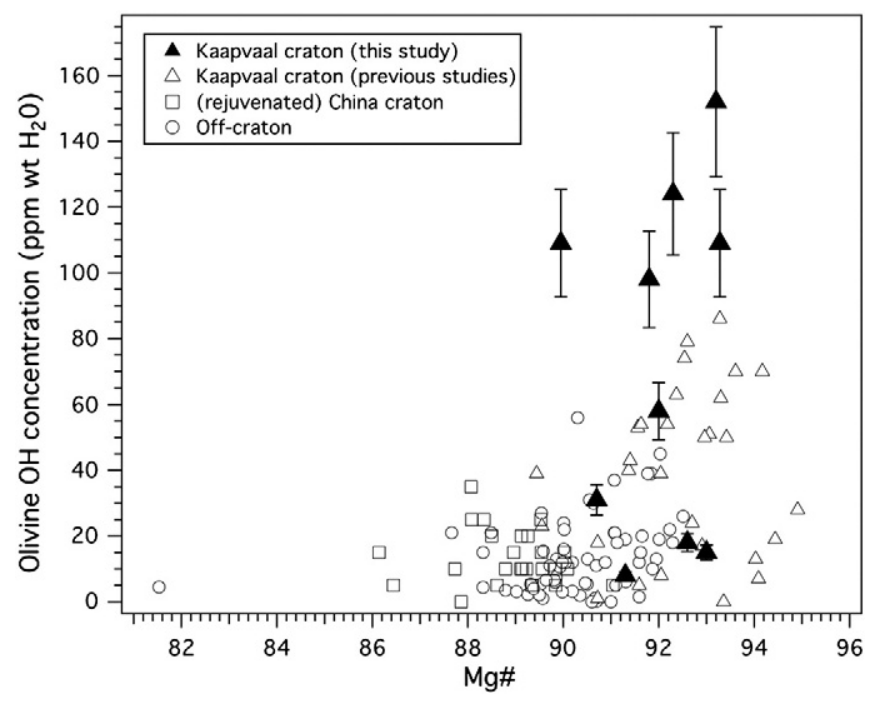

Fig. 13. OH concentration versus mg\# in olivine. For comparison, data obtained in previous studies on peridotite xenoliths from various localities are also shown (Bell et al., 2004; Demouchy et al., 2006; Falus et al., 2008).
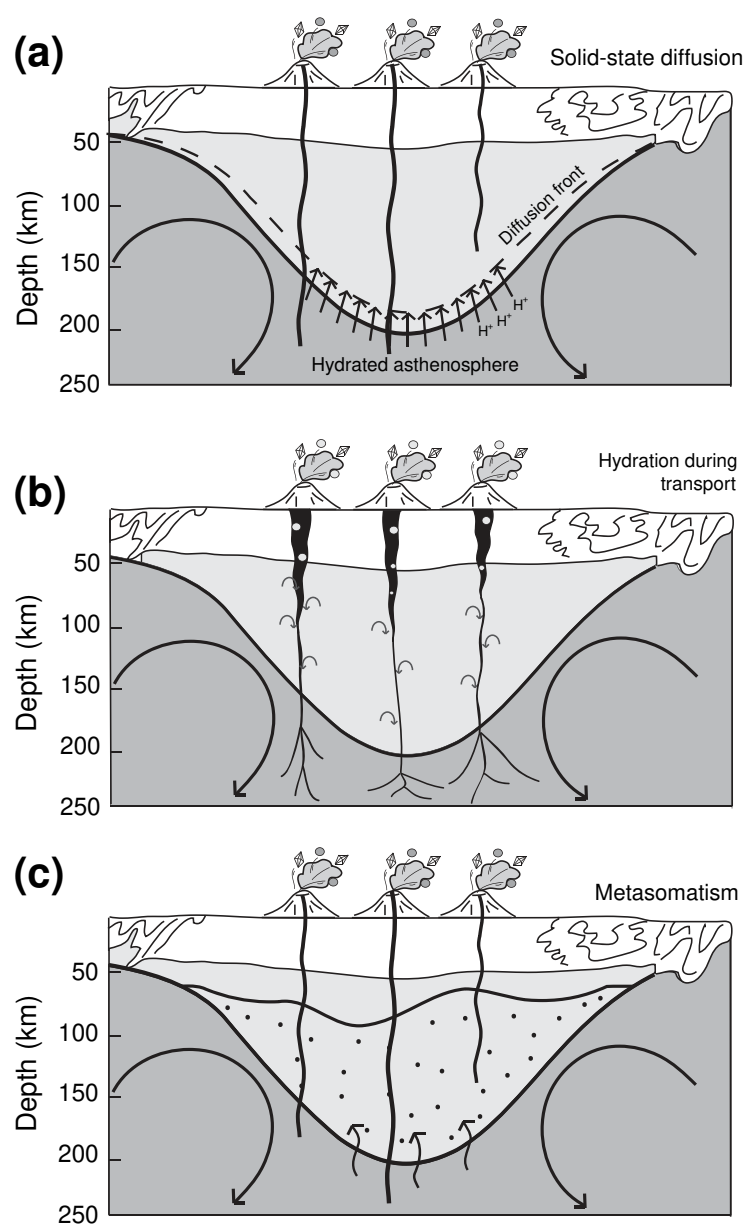

Fig. 14. Sketches illustrating the three scenarii proposed to explain the variation of $\mathrm{OH}^{-}$concentration in olivine with depth in the Kaapvaal craton root.

secondary garnet, clinopyroxene and phlogopite (Fig. $3 \mathrm{~b}$ and $\mathrm{d}$; Grégoire et al., 2003; Simon et al., 2007). In this case, hydration may be both spatially and temporally heterogeneous, since it may be related to many distinct metasomatic episodes: from (i) early metasomatism by Si- and volatile-rich fluids that produced the high modal content of orthopyroxene in Kaapvaal harzburgites (Bell et al., 2005), which was proposed, based on Lu-Hf and Sm-Nd model ages, to be multiple episodes between $1.3 \mathrm{Ga}$ and $600 \mathrm{Ma}$ (Wasch et al., 2009), to (ii) late metasomatism by K-rich melts, which has caused phlogopite crystallization (Grégoire et al., 2003; Simon et al., 2007). This spatial and temporal variability is coherent with the $\mathrm{OH}^{-}$concentration heterogeneity of the Kaapvaal olivines (Fig. 10).

In scenarios $\mathrm{B}$ and $\mathrm{C}$, the observed vertical variation in $\mathrm{OH}^{-}$concentrations may be accounted by considering the relative changes in water and carbon activity with pressure in volatile-rich (C-O-H) fluids, which at pressures $>5 \mathrm{GPa}$, have high carbon and low water activities (Dixon et al., 1995; Newman and Lowenstern, 2002) and the variation in the mantle redox state with depth, as proposed by Peslier et al. (2010). If metasomatism is associated with percolation of basaltic magmas, change in the melt composition with progressive enrichment in volatiles during reactive percolation (O'Nions and McKenzie, 1988) may also account for the contrast in $\mathrm{OH}^{-}$contents between the deepest and intermediate depth peridotites.

The two last scenarios have different implications for the cratonic root stability. In the first one, the root is essentially dry and the high water contents in olivine measured in the present study and in previous studies result from "contamination" during the ascent in the kimberlitic magma. In the second one, metasomatism may have hydrated and, hence, weakened at least parts of the cratonic root after 
its formation. The very nature of xenolithic sampling by kimberlites prevents the evaluation of the actual volumes of the mantle affected by the metasomatic processes. Comparison between the magnetotelluric electrical conductivity data in a station close to Jagersfontein and the MT signal modeled using a constant water concentration in the cratonic mantle or a variation in water contents with depth similar to the one observed in this study (cf. the Fig. 8 in Fullea et al., 2011) suggests however that the vertical variation of water contents in olivine observed in the present study and in Peslier et al. (2010) may be representative of the present-day hydration state of the Kaapvaal mantle, favoring the last scenario and implying that metasomatism resulted in extensive re-hydration of the cratonic mantle at intermediate depths.

The annealed microstructures of Kaapvaal peridotites indicate however that rehydration was not followed by remobilization of the cratonic root. Several explanations may be proposed: (i) the extensive hydration of the intermediate depths of the cratonic root is recent and its mechanical effects have not been felt yet, (ii) the distribution of the hydrated domains is too heterogeneous, or (iii) the dry layer at its base (Fig. 10) protects the craton root from thermo-mechanical erosion by the convective mantle as proposed by Peslier et al. (2010). The latter hypothesis is appealing, but convective models testing the stability of a block with thickened lithosphere is largely eroded from its sides (edge-driven convection), unless it is $>10$ times wider than thick (Morency et al., 2002). This implies that a high strength layer at the base of the cratonic root may not be enough to ensure its preservation.

\section{Conclusions}

Coarse-granular refractory harzburgites predominate in the Kaapvaal mantle, being observed in all studied pipes at all depths. Their highly recovered microstructures and very coarse grain sizes contrast with the olivine and orthopyroxene CPO, indicating that deformation by dislocation creep was followed by effective annealing. This supports an early deformation episode, possibly associated to the formation of the cratonic root in the Archean, followed by slow cooling and a long quiescence time. Fluid-enhanced grain boundary migration during the multiple metasomatic events that affected the Kaapvaal mantle may also have favored annealing. Coarseporphyroclastic peridotites are rarer, but present at all depths in Kimberley and in deep levels in Finsch and Premier. They represent domains less annealed or deformed shortly before extraction. Sheared peridotites with mylonitic, fluidal or mosaic microstructures, are common below $140 \mathrm{~km}$ depth. Their fine recrystallized grain sizes and high equilibrium temperatures imply deformation under high stress and high strain rates, not consistent with a quasi-stationary mantle flow at the lithosphere-asthenosphere boundary.

Textures and compositions of the studied xenoliths provide evidence for multiple metasomatic events with a spatially heterogeneous distribution. Analysis of the microstructures and comparison between the olivine and secondary mineral CPOs indicate that silica-enrichment episodes, which resulted in high modal orthopyroxene, were pre- to postkinematic, and that metasomatism by K-rich fluids or melts and refertilization was post-kinematic. Deformation of phlogopite and clinopyroxene in the sheared peridotites implies that mylonitization postdated all metasomatic events.

Water contents in olivine are strongly variable, but tend to increase with depth up to $150 \mathrm{~km}$, where they are among the highest measured in mantle peridotites ( $\sim 150$ wt. ppm $\mathrm{H}_{2} \mathrm{O}$; Bell et al., 2003 calibration). The deepest analyzed samples are, in contrast, almost dry. High water contents in coarse-grained peridotites are not accompanied by dominant activation of [001] glide. The bimodal olivine CPO in sheared peridotites indicates nevertheless activation of both [100] and [001] glide on the (010) plane, probably due to high pressure and stresses.
Lack of correlation between olivine mg\# and water content indicates that the high water contents in olivine record re-hydration after formation of the refractory mantle root. Hydration of olivine may have occurred during either extraction of the peridotites by volatile-rich kimberlites or metasomatism by water-rich fluids/ melts. Magnetotelluric electrical conductivity data in the central Kaapvaal is, however, best explained by models with a vertical variation of water contents in olivine similar to the one measured here, suggesting that the observed water contents in olivine may be representative of the present-day hydration state of the Kaapvaal mantle, favoring the metasomatism scenario. The predominance of highly annealed microstructures in the cratonic root indicates nevertheless that this re-hydration did not result in remobilization of the cratonic root.

\section{Acknowledgments}

The authors thank A. Vauchez, J-M. Dautria, and S. Keshav for helpful discussions. C. Nevado and D. Delmas are thanked for providing high-quality polishing of sections for EBSD measurements. Electron microprobe analyses were carried out with the help of $\mathrm{C}$. Merlet at the Service Microsonde Sud, Universite Montpellier 2. FTIR analyses were performed with the assistance of D. Maurin at the Lab. Colloids, Verre et Nanomateriaux, at Universite Montpellier 2, France. AT has been funded by CRYSTAL2PLATE, a EU FP7-funded Marie Curie Action under grant agreement PITN-GA-2008-215353. The EBSD-SEM national facility in Montpellier is supported by the Institut National de Sciences de l'Univers (INSU) du Centre National de la Recherche Scientifique (CNRS), France and by the Conseil Régional Languedoc-Roussillon, France.

\section{References}

Allsopp, H.L., Bristow, J.W., Skinner, E.M.W., 1985. The Rb-Sr geochronology of the Colossus kimberlite pipe, Zimbabwe. Transactions of the Geological Society of South Africa 88, 245-248.

Austin, N.J., Evans, B., 2007. Paleowattmeters: a scaling relation for dynamically recrystallized grain size. Geology 35, 343-346.

Bai, Q., Kohlstedt, D.L., 1993. Effects of chemical environment on the solubility and incorporation mechanism for hydrogen in olivine. Physics and Chemistry of Minerals 19, 460-471.

Bali, E., Bolfan-Casanova, N., Koga, K.T., 2008. Pressure and temperature dependence of $\mathrm{H}$ solubility in forsterite: an implication to water activity in the Earth interior. Earth and Planetary Science Letters 268, 354-363.

Bascou, J., Tommasi, A., Mainprice, D., 2002. Plastic deformation and development of clinopyroxene lattice preferred orientations in eclogites. Journal of Structural Geology 24, 1357-1368.

Bascou, J., Delpech, G., Vauchez, A., Moine, B.N., Cottin, J.Y., Barruol, G., 2008. An integrated study of microstructural, geochemical, and seismic properties of the lithospheric mantle above the Kerguelen plume (Indian Ocean). Geochemistry Geophysics, Geosystems 9, Q04036. http://dx.doi.org/10.1029/2007GC001879.

Bascou, J., Doucet, L.S., Saumet, S., Ionov, D.A., Ashchepkov, I.V., Golovin, A.V., 2011 Seismic velocities, anisotropy and deformation in Siberian cratonic mantle: EBSD data on xenoliths from the Udachnaya kimberlite. Earth and Planetary Science Letters 304, 71-84.

Begg, G.C., Griffin, W.L., Natapov, L.M., O'Reilly, S.Y., Grand, S.P., O'Neill, C.J., Hronsky, J.M.A., Poudjom Djomani, Y., Swain, C.J., Deen, T., Bowden, P., 2009. The lithospheric architecture of Africa: seismic tomography, mantle petrology, and tectonic evolution. Geosphere 5, 23-50.

Bell, D.R., Rossman, G.R., Maldener, J., Endisch, D., Rauch, F., 2003. Hydroxide in olivine: a quantitative determination of the absolute amount and calibration of the IR spectrum. Journal of Geophysical Research 108, 2105. http://dx.doi.org/10.1029/ 2001JB000679.

Bell, D.R., Rossman, G.R., Moore, R.O., 2004. Abundance and partitioning of $\mathrm{OH}$ in a high-pressure magmatic system: megacrysts from the Monastery kimberlite, South Africa. Journal of Petrology 45, 1539-1564.

Bell, D., Grégoire, M., Grove, T., Chatterjee, N., Carlson, R., Buseck, P., 2005. Silica and volatile-element metasomatism of Archean mantle: a xenolith-scale example from the Kaapvaal craton. Contributions to Mineralogy and Petrology 150, 251-267.

Ben Ismaïl, W., 1999. La lithosphère cratonique: pétrophysique des xénolites mantelliques d'Afrique du Sud. PhD Thesis, Université de Montpellier II, 245 pp.

Ben Ismaïl, W., Mainprice, D., 1998. An olivine fabric database: an overview of upper mantle fabrics and seismic anisotropy. Tectonophysics 296, 145-157. 
Ben Ismaïl, W., Barruol, G., Mainprice, D., 2001. The Kaapvaal craton seismic anisotropy: petrophysical analyses of upper mantle kimberlite nodules. Geophysical Research Letters 28, 13. http://dx.doi.org/10.1029/2000GL012419.

Berry, A.J., O'Neill, H.S.C., Hermann, J., Scott, D.R., 2007. The infrared signature of water associated with trivalent cations in olivine. Earth and Planetary Science Letters 261, 134-142.

Bolfan-Casanova, N., 2005. Water in the Earth's mantle. Mineralogical Magazine 69, 229-257.

Boullier, A.M., 1977. Structure des péridotites en enclaves dans les kimberlites d'Afrique du Sud. Conséquences sur la constitution du manteau supérieur. Bulletin de la Société Française de Minéralogie et Cristallographie 100, 214-229.

Boullier, A.M., Gueguen, Y., 1975. SP-mylonites: origin of some mylonites by superplastic flow. Contributions to Mineralogy and Petrology 50, 93-104.

Boullier, A.M., Nicolas, A., 1975. Classification of textures and fabrics of peridotite xenoliths from South African kimberlites. Physics and Chemistry of the Earth 9, 467-476.

Boyd, F.R., Mertzman, S.A., 1987. Composition and structure of the Kaapvaal lithosphere. In: Mysen, B.O. (Ed.), Magmatic Processes: Physiochemical Principles. Geochemical Society Special Publications, Washington, DC, pp. 13-24.

Boyd, F.R., Nixon, P.H., 1975. Origins of the ultramafic nodules from some kimberlites of northern Lesotho and the Monastery Mine, South Africa. Physics and Chemistry of the Earth 9, 431-454.

Boyd, F.R., Nixon, P.H., 1978. Ultramafic nodules from the Kimberley pipes, South Africa. Geochimica et Cosmochimica Acta 42 (9), 1367-1371 1373-1382.

Boyd, F.R., Gurney, J.J., Richardson, S.H., 1985. Evidence for a 150-200-km thick archean lithosphere from diamond inclusion thermobarometry. Nature 315, 387-389.

Brey, G.P., Köhler, T., 1990. Geothermobarometry in four-phase Lherzolites II. New thermobarometers, and practical assessment of existing thermobarometers. Journal of Petrology 31, 1353-1378.

Chevrot, S., Zhao, L., 2007. Multiscale finite-frequency Rayleigh wave tomography of the Kaapvaal craton. Geophysical Journal International 169, 201-215.

Couvy, H., Frost, D.J., Heidelbach, F., Nyilas, K., Ungar, T., Mackwell, S., Cordier, P., 2004 Shear deformation experiments of forsterite at $11 \mathrm{GPa}-1400{ }^{\circ} \mathrm{C}$ in the multianvil apparatus. European Journal of Mineralogy 16, 877-889.

Davis, G.L., 1977. The ages and uranium contents of zircons from kimberlites and associated rocks. Carnegie Institution of Washington Year Book 76, 631-635.

Davis, G.L., 1978. Zircons from the mantle. US Geological Survey Open-File Report 78 701, pp. 86-88

de Wit, M.J., Roering, Ch., Hart, R.G., Armstrong, R.A., de Ronde, C.E.G., Green, R.W.E Tredoux, M., Pederby, E., Hart, R.A., 1992. Formation of an Archean Continent Nature $357,553-562$.

Demouchy, S., 2010. Diffusion of hydrogen in olivine grain boundaries and implications for the survival of water-rich zones in the Earth's mantle. Earth and Planetary Science Letters 295, 305-313.

Demouchy, S., Mackwell, S., 2006. Mechanisms of hydrogen incorporation and diffusion in iron-bearing olivine. Physics and Chemistry of Minerals 33, 347-355.

Demouchy, S., Jacobsen, S.D., Gaillard, F., Stern, C.R., 2006. Rapid magma ascent recorded by water diffusion profiles in mantle olivine. Geology 34, 429-432.

Demouchy, S., Schneider, S.E., Mackwell, S.J., Zimmerman, M.E., Kohlstedt, D.L., 2009. Experimental deformation of olivine single crystals at lithospheric temperatures. Geophysical Research Letters 36, L04304. http://dx.doi.org/10.1029/2008GL036611.

Dixon, J.E., Stolper, E.M., Holloway, J.R., 1995. An experimental study of water and carbon dioxide solubilities in mid-ocean ridge basaltic liquids. Part I: Calibration and solubility models. Journal of Petrology 36, 1607-1631.

Dixon, J.E., Leist, L., Langmuir, C., Schilling, J.-G., 2002. Recycled dehydrated lithosphere observed in plume-influenced mid-ocean-ridge basalt. Nature 420, 385-389.

Doin, M.-P., Fleitout, L., Christensen, U., 1997. Mantle convection and stability of depleted and undepleted continental lithosphere. Journal of Geophysical Research 102, 2771-2787.

Drury, M.R., Van Roermund, H.L.M., 1989. Fluid assisted recrystallization in upper mantle peridotite xenoliths from kimberlites. Journal of Petrology 30,133-152.

Duclos, M., K.S.M., Tommasi, A., Gledhill, K.R., 2005. Mantle tectonics beneath New Zealand inferred from SKS splitting and petrophysics. Geophysical Journal International 163, 760-774.

Durham, W.B., Goetze, C., 1977. Plastic flow of oriented single crystals of olivine 1. Mechanical data. Journal of Geophysical Research 82 (36), 5737-5754.

Eaton, D.W., Darbyshire, F., Evans, R.L., Grütter, H., Jones, A.G., Yuan, X., 2009. The elusive lithosphere-asthenosphere boundary (LAB) beneath cratons. Lithos 109, 1-22.

Eggler, D.H., Furlong, K.P., 1991. Destruction of subcratonic mantle keel: the Wyoming province. 5th Kimberlite Conference Extended Abstracts, pp. 85-87.

Evans, R.L., Jones, A.G., Garcia, X., Muller, M., Hamilton, M., Evans, S., Fourie, C.J.S. Spratt, J., Webb, S., Jelsma, H., Hutchins, D., 2011. Electrical lithosphere beneath the Kaapvaal craton, southern Africa. Journal of Geophysical Research 116, B04105.

Falus, G., Tommasi, A., Ingrin, J., Szabó, C., 2008. Deformation and seismic anisotropy of the lithospheric mantle in the southeastern Carpathians inferred from the study of mantle xenoliths. Earth and Planetary Science Letters 272, 50-64.

Falus, G., Tommasi, A., Soustelle, V., 2011. Effect of dynamic recrystallization on olivine crystal preferred orientations in mantle xenoliths deformed under varied stress conditions. Journal of Structural Geology 33, 1528-1540.

Ferot, A., 2011. Etude expérimentale à haute pression et haute température du stockage et de la distribution de l'eau dans le manteau supérieur terrestre. Université Blaise Pascal, Clermont-Ferrand II. 259 pp.

Finnerty, A.A., Boyd, F.R., 1987. Thermobarometry for garnet peridotite xenoliths: a basis for mantle stratigraphy. In: Nixon, P.H. (Ed.), Mantle Xenoliths. Wiley, New York, pp. 381-402.
Frets, E., Tommasi, A., Garrido, C., Padron-Navarta, J.A., Amri, I., Targuisti, K., 2012. Deformation processes and rheology of pyroxenites under lithospheric mantle conditions. Journal of Structural Geology 39, 138-157. http://dx.doi.org/10.1016/j.jsg.2012.02.019.

Fullea, J., Muller, M.R., Jones, A.G., 2011. Electrical conductivity of continental lithospheric mantle from integrated geophysical and petrological modeling: application to the Kaapvaal Craton and Rehoboth Terrane, southern Africa. Journal of Geophysical Research 116, B10202. http://dx.doi.org/10.1029/2011JB008544.

Goetze, C., 1975. Sheared lherzolites: from the point of view of rock mechanics. Geology $3,172-173$

Grant, K., Ingrin, J., Lorand, J., Dumas, P., 2007. Water partitioning between mantle minerals from peridotite xenoliths. Contributions to Mineralogy and Petrology 154, $15-34$.

Green, H.W., Gueguen, Y., 1974. Origin of kimberlite pipes by diapiric upwelling in upper mantle. Nature 249, 617-620.

Green, D.H., Hibberson, W.O., Kovacs, I., Rosenthal, A., 2010. Water and its influence on the lithosphere-asthenosphere boundary. Nature 467, 448-451.

Grégoire, M., Bell, D.R., Le Roex, A.P., 2003. Garnet lherzolites from the Kaapvaal craton (South Africa): trace element evidence for a metasomatic history. Journal of Petrology 44, 629-657.

Griffin, W.L., O'Reilly, S.Y., Natapov, L.M., Ryan, C.G., 2003. The evolution of lithospheric mantle beneath the Kalahari Craton and its margins. Lithos 71, 215-241.

Griffin, W.L., Graham, S., O'Reilly, S.Y., Pearson, N.J., 2004. Lithosphere evolution beneath the Kaapvaal Craton: Re-Os systematics of sulfides in mantle-derived peridotites. Chemical Geology 208, 89-118.

Hirschmann, M.M., Aubaud, C., Withers, A.C., 2005. Storage capacity of $\mathrm{H}_{2} \mathrm{O}$ in nominally anhydrous minerals in the upper mantle. Earth and Planetary Science Letters 236, 167-181.

Hirth, G., Kohlstedt, D., 2003. Rheology of the upper mantle and the mantle wedge: a view from the experimentalists. AGU Geophysical Monograph 138, 83-105.

James, D.E., Fouch, M.J., Vandecar, J.C., Van der Lee, S., 2001. Tectospheric structure beneath southern Africa: the Kaapvaal Project: formation and evolution of cratons. Geophysical Research Letters 28, 2485-2488.

James, D.E., Niu, F., Rokosky, J., 2003. Crustal structure of the Kaapvaal craton and its significance for early crustal evolution. Lithos 71, 413-429.

James, D.E., Boyd, F.R., Schutt, D., Bell, D.R., Carlson, R.W., 2004. Xenolith constraints on seismic velocities in the upper mantle beneath southern Africa. Geochemistry, Geophysics, Geosystems 5, Q01002.

Jaupart, C., Mareschal, J.C., 1999. The thermal structure and thickness of continental roots. Lithos 48, 93-114.

Jordan, T.H., 1978. Composition and development of continental tectosphere. Nature 274, 544-548.

Jung, H., Katayama, I., Jiang, Z., Hiraga, T., Karato, S., 2006. Effect of water and stress on the lattice-preferred orientation of olivine. Tectonophysics 421, 1-22.

Jung, H., Mo, W., Green, H.W., 2008. Upper mantle seismic anisotropy resulting from pressure-induced slip transition in olivine. Nature Geoscience 2, 73-77.

Kamenetsky, V.S., Kamenetsky, M.B., Sobolev, A.V., Golovin, A.V., Demouchy, S., Faure, K., Sharygin, V.V., Kuzmin, D.V., 2008. Olivine in the Udachnaya-East kimberlite (Yakutia, Russia): types, compositions and origins. Journal of Petrology 49 (4), 823-839.

Keefner, J.W., Mackwell, S.J., Kohlstedt, D.L., Heidelbach, F., 2011. Dependence of dislocation creep of dunite on oxygen fugacity: implications for viscosity variations in Earth's mantle. Journal of Geophysical Research 116, B05201.

Kelemen, P.B., Hart, S.R., Bernstein, S., 1998. Silica enrichment in the continental upper mantle via melt/rock reaction. Earth and Planetary Science Letters 164, 387-406.

Kennedy, L.A., Russell, J.K., Kopylova, M.G., 2002. Mantle shear zones revisited: the connection between the cratons and mantle dynamics. Geology 30, 419-422.

Kohlstedt, D.L., Keppler, H., Rubie, D.C., 1996. Solubility of water in the alpha, beta, and gamma phases of $(\mathrm{Mg}, \mathrm{Fe})_{2} \mathrm{SiO}_{4}$. Reviews in Mineralogy and Geochemistry 123, 345-357.

Kovacs, I., O'Neill, H.C.J., Hermann, J., Hauri, E.H., 2010. Site-specific infrared O-H absorption coefficients for water substitution into olivine. American Mineralogist 95, 292-299.

Kramers, J.D., Smith, C.B., 1983. A feasibility study of U-Pb and Pb-Pb dating of kimberlites using groundmass mineral fractions and whole-rock samples. Chemical Geology $41,23-38$

Kurosawa, M., Yurimoto, H., Sueno, S., 1997. Patterns in the hydrogen and trace element compositions of mantle olivines. Physics and Chemistry of Minerals 24, 385-395.

Le Roux, V., Bodinier, J.-L., Tommasi, A., Alard, O., Dautria, J.-M., Vauchez, A., Riches, A.J.V., 2007. The Lherz spinel lherzolite: refertilized rather than pristine mantle. Earth and Planetary Science Letters 259, 599-612.

Le Roux, V., Tommasi, A., Vauchez, A., 2008. Feedback between melt percolation and deformation in an exhumed lithosphere-asthenosphere boundary. Earth and Planetary Science Letters 274, 401-413.

Lenardic, A., Moresi, L.-N., 1999. Some thoughts on the stability of cratonic lithosphere: effects of buoyancy and viscosity. Journal of Geophysical Research 104, $12,747-12,758$

Lenardic, A., Moresi, L.N., Muhlhaus, H., 2003. Longevity and stability of cratonic lithosphere: insights from numerical simulations of coupled mantle convection and continental tectonics. Journal of Geophysical Research 108, 2303. http:// dx.doi.org/10.1029/2002JB001859.

Li, J., Kornprobst, J., Vielzeuf, D., Fabriès, J., 1995. An improved experimental calibration of the olivine-spinel geothermometer. Chinese Journal of Geochemistry 14, 68-77.

Li, Z.-X.A., Lee, C.-T.A., Peslier, A.H., Lenardic, A., Mackwell, S.J., 2008. Water contents in mantle xenoliths from the Colorado Plateau and vicinity: implications for the 
mantle rheology and hydration-induced thinning of continental lithosphere. Journal of Geophysical Research 113, B09210.

Malkovets, V.G., Griffin, W.L., O'Reilly, S.Y., Wood, B.J., 2007. Diamond, subcalcic garnet, and mantle metasomatism: kimberlite sampling patterns define the link. Geology $35,339-342$.

McIntyre, R.M., Dawson, J.B., 1976. Age and significance of some South African kimberlites. Abstracts of the 4th European Colloquium on Geochronology, Cosmochemistry and Isotope Geology, Amsterdam, the Netherlands. Abstract, 66

Menzies, M.A., Fan, W., Zhang, M., 1993. Palaeozoic and Cenozoic lithoprobes and the loss of $>120 \mathrm{~km}$ of Archean lithosphere, Sino-Korean craton, China. Geological Society of London, Special Publication 76, 71-81.

Miller, G.H., Rossman, G.R., Harlow, G.E., 1987. The natural occurrence of hydroxide in olivine. Physics and Chemistry of Minerals 14, 461-472.

Moore, R.O., 1986. A study of the kimberlite, diamonds and associated rocks and minerals from the Monastery mine, South Africa. PhD Thesis. University of Cape Town, $251 \mathrm{pp}$.

Morales, L.F.G., Tommasi, A., 2011. Composition, textures, seismic and thermal anisotropies of xenoliths from a thin and hot lithospheric mantle (Summit Lake, southern Canadian Cordillera). Tectonophysics 507, 1-15.

Morency, C., Doin, M.P., Dumoulin, C., 2002. Convective destabilization of a thickened continental lithosphere. Earth and Planetary Science Letters 202, 303-320.

Newman, S., Lowenstern, J.B., 2002. VOLATILECALC: a silicate melt- $\mathrm{H}_{2} \mathrm{O}-\mathrm{CO}_{2}$ solution model written in Visual Basic for excel. Computers and Geosciences 28, 597-604.

Nickel, K.G., Green, D.H., 1985. Empirical geothermobarometry for garnet peridotites and implications for the nature of the lithosphere, kimberlites and diamonds. Earth and Planetary Science Letters 73, 158-170.

Nixon, P.H., Rogers, N.W., Gibson, I.L., Grey, A., 1981. Depleted and fertile mantle xenoliths from southern African kimberlites. Annual Review of Earth and Planetary Sciences 9, 285-309.

O'Reilly, S.Y., Griffin, W.R., 2010. The continental lithosphere-asthenosphere boundary: can we sample it ? Lithos 120,1-13.

O'Neill, H.S.C., Wood, B.J., 1979. An experimental study of Fe-Mg partitioning between garnet and olivine and its calibration as a geothermometer. Contributions to Mineralogy and Petrology 70, 59-70.

O'Nions, R.K., McKenzie, D.P., 1988. Melting and continents generation. Earth and Planetary Science Letters 90, 449-456.

Paterson, M.S., 1982. The determination of hydroxyl by infrared absorption in quartz, silicate glasses and similar materials. Bulletin de Mineralogie 105, 20-29.

Pearson, D.G., Carlson, R.W., Shirey, S.B., Boyd, F.R., Nixon, P.H., 1995. Stabilisation of Archean lithospheric mantle: a Re-Os isotope study of peridotite xenoliths from the Kaapvaal craton. Earth and Planetary Science Letters 134, 341-357.

Pera, E., Mainprice, D., Burlini, L., 2003. Anisotropic seismic properties of the upper mantle beneath the Torre Alfina area (Northern Apennines, Central Italy). Tectonophysics 370, 11-30.

Peslier, A.H., Luhr, J.F., 2006. Hydrogen loss from olivines in mantle xenoliths from Simcoe (USA) and Mexico: mafic alkalic magma ascent rates and water budget of the sub-continental lithosphere. Earth and Planetary Science Letters 242, 302-319.

Peslier, A.H., Luhr, J.F., Post, J., 2002. Low water contents in pyroxenes from spinel peridotites of the oxidized, sub-arc mantle wedge. Earth and Planetary Science Letters 201, 69-86.

Peslier, A.H., Woodland, A.B., Wolff, J.A., 2008. Fast kimberlite ascent rates estimated from hydrogen diffusion profiles in xenolithic mantle olivines from southern Africa. Geochimica et Cosmochimica Acta 72, 2711-2722.

Peslier, A.H., Woodland, A.B., Bell, D.R., Lazarov, M., 2010. Olivine water contents in the continental lithosphere and the longevity of cratons. Nature 467, 78-81.

Phillips, D., Machin, K.J., Kiviets, G.B., Fourie, L.F., Roberts, M.A., Skinner, E.M.W., 1998. A petrographic and ${ }^{40} \mathrm{Ar} /{ }^{39} \mathrm{Ar}$ geochronological study of the Voorspoed kimberlite, South Africa: implications for the origin of Group II kimberlite magmatism. South African Journal of Geology 101, 299-306.

Pollack, H.N., 1986. Cratonization and thermal evolution of the mantle. Earth and Planetary Science Letters 80, 175-182.

Post, J.L., Borer, L., 2000. High-resolution infrared spectra, physical properties, and micromorphology of serpentines. Applied Clay Science 16, 73-85.

Raterron, P., Chen, J., Li, L., Weidner, D., Cordier, P., 2007. Pressure-induced slip-system transition in forsterite: single-crystal rheological properties at mantle pressure and temperature. American Mineralogist 92, 1436-1445.
Riley, T.R., Leat, P.T., Curtis, M.L., Millar, I.L., Duncan, R.A., Fazel, A., 2005. Early Middle Jurassic dolerite dykes from Western Dronning Maud Land (Antarctica): identifying mantle sources in the Karoo large igneous province. Journal of Petrology 46 1489-1524.

Scoates, J.S., Friedman, R.M., 2008. Precise age of the platiniferous Merensky Reef Bushveld complex, South Africa, by the U-Pb zircon chemical abrasion ID-TIMS technique. Economic Geology 103, 465-471.

Shirey, S.B., Harris, J.W., Richardson, S.H., Fouch, M.J., James, D.E., Cartigny, P., Deines, P., Viljoen, F., 2002. Diamond genesis, seismic structure, and evolution of the Kaapvaal-Zimbabwe craton. Science 297, 1683-1686.

Simon, N.S.C., Carlson, R.W., Pearson, D.G., Davies, G.R., 2007. The origin and evolution of the Kaapvaal cratonic lithospheric mantle. Journal of Petrology 48, 589-625.

Skemer, P., Karato, S.-I., 2008. Sheared Iherzolite xenoliths revisited. Journal of Geophysical Research 113, B07205.

Skogby, H., Bell, D.R., Rossman, G.R., 1990. Hydroxide in pyroxene; variations in the natural environment. American Mineralogist 75, 764-774

Smith, C.B., Allsopp, H.L., Kramers, J.D., Hutchinson, G., Roddick, J.C., 1985. Emplacement ages of Jurassic-Cretaceous South African kimberlites by the Rb-Sr method on phlogopite and whole-rock samples. Transactions of the Geological Society of South Africa 88, 249-266.

Soustelle, V., Tommasi, A., Bodinier, J.-L., Garrido, C.J., Vauchez, A., 2009. Deformation and reactive melt transport in the mantle lithosphere above a large-scale partial melting domain: the Ronda peridotite massif, southern Spain. Journal of Petrology $50,1235-1266$.

Soustelle, V., Tommasi, A., Demouchy, S., Ionov, D.A., 2010. Deformation and fluid, a rock interaction in the supra-subduction mantle: microstructures and water contents in peridotite xenoliths from the Avacha Volcano, Kamchatka. Journal of Petrology 51, 363-394.

Stachel, T., Harris, J.W., Tappert, R., Brey, G.P., 2003. Peridotitic diamonds from the Slave and the Kaapvaal cratons-similarities and differences based on a preliminary data set. Lithos 71, 489-503.

Tommasi, A., Tikoff, B., Vauchez, A., 1999. Upper mantle tectonics: three-dimensional deformation, olivine crystallographic fabrics and seismic properties. Earth and Planetary Science Letters 168, 173-186.

Tommasi, A., Mainprice, D., Canova, G., Chastel, Y., 2000. Viscoplastic self-consistent and equilibrium-based modeling of olivine lattice preferred orientations: implications for the upper mantle seismic anisotropy. Journal of Geophysical Research 105, 7893-7908.

Tommasi, A., Godard, M., Coromina, G., Dautria, J.-M., Barsczus, H., 2004. Seismic anisotropy and compositionally induced velocity anomalies in the lithosphere above mantle plumes: a petrological and microstructural study of mantle xenoliths from French Polynesia. Earth and Planetary Science Letters 227, 539-556.

Tommasi, A., Vauchez, A., Godard, M., Belley, F., 2006. Deformation and melt transport in a highly depleted peridotite massif from the Canadian Cordillera: implications to seismic anisotropy above subduction zones. Earth and Planetary Science Letters 252, 245-259.

Tommasi, A., Vauchez, A., Ionov, D.A., 2008. Deformation, static recrystallisation, and reactive melt transport in shallow subcontinental mantle xenoliths (Tok Cenozoic volcanic field, SE Siberia). Earth and Planetary Science Letters 272, 65-77.

Vauchez, A., Garrido, C.J., 2001. Seismic properties of an asthenospherized lithospheric mantle: constraints from the lattice preferred orientations in peridotite from the Ronda massif. Earth and Planetary Science Letters 192, 235-249.

Vauchez, A., Dineur, F., Rudnick, R.L., 2005. Microstructure, texture and seismic anisotropy of the lithospheric mantle above a mantle plume: insights from the Labait volcano xenoliths. Earth and Planetary Science Letters 232, 295-314.

Wasch, L.J., van der Zwan, F.M., Nebel, O., Morel, M.L.A., Hellebrand, E.W.G., Pearson, D.G., Davies, G.R., 2009. An alternative model for silica enrichment in the Kaapvaal subcontinental lithospheric mantle. Geochimica et Cosmochimica Acta 73, 6894-6917.

Yang, X.-Z., Xia, Q.K., Deloule, E., Dallai, L., Fan, Q.-C., Feng, M., 2008. Water in minerals of the continental lithospheric mantle and overlying lower crust: a comparative study of peridotite and granulite xenoliths from the North China Craton. Chemical Geology 256, 33-45 